WORKING PAPER · NO. 2020-59

COVID-19 Is Also a Reallocation Shock

Jose Maria Barrero, Nick Bloom, and Steven J. Davis

JUNE 2020

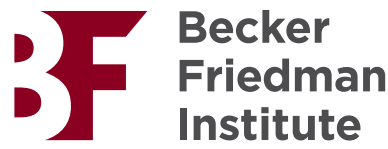




\title{
COVID-19 Is Also a Reallocation Shock
}

\author{
Jose Maria Barrero, Nick Bloom and Steven J. Davis
}

5 May 2020, last edited on 25 June 2020

\begin{abstract}
Drawing on firm-level forecasts at a one-year horizon in the Survey of Business Uncertainty (SBU), we construct novel, forward-looking reallocation measures for jobs and sales. These measures rise sharply after February 2020, reaching rates in April that are 2.4 (3.9) times the preCOVID average for jobs (sales). We also draw on special SBU questions to estimate that the COVID-19 shock caused 3 new hires for every 10 layoffs, that 32-42\% of COVID-induced layoffs will be permanent, and that one-tenth of all work days (one-fifth for office workers) will shift from business premises to residences in the post-pandemic world relative to the pre-pandemic situation. Our survey evidence aligns well with anecdotal evidence of large pandemic-induced demand increases at many firms, evidence on job openings, gross job creation and gross business formation, and a sharp pandemic-induced rise in equity return dispersion across firms. After developing the evidence, we consider implications for the economic outlook and for policy responses to the pandemic. Unemployment benefit levels that exceed worker earnings, policies that subsidize employee retention, land-use restrictions, occupational licensing restrictions, and regulatory barriers to business formation will impede reallocation responses to the COVID-19 shock.
\end{abstract}

JEL Numbers: D22, D84, E24, H12, H25, J21, J62, J63, J65, R32

Keywords: COVID-19, coronavirus, reallocation shock, layoffs, working from home, Survey of Business Uncertainty, CARES Act

Acknowledgements: We thank Katherine Abraham, Dave Altig, Joseph Beaulieu, Jason Cummins, Marianna Kudlyak, Eddie Lazear, Brent Meyer, Adam Milsap, Giuseppe Moscarini, Jim Stock and seminar participants at CBO, IGIER and the IMF for helpful comments and Emil Mihaylov for outstanding research assistance. We thank Akhtar Muhammad and Till von Wachter for supplying data on the temporary-layoff share of new unemployment claims in California. We gratefully acknowledge financial support from the Federal Reserve Bank of Atlanta, the Sloan Foundation, Stanford University, and the University of Chicago Booth School of Business. 
The COVID-19 pandemic and efforts to contain the virus are exacting a staggering economic toll in countries around the world. China's economy shrank 6.8 percent in the first quarter of 2020 on a year-on-year basis, and Eurozone economies shrank at a 14.8 percent annualized rate. In the United States, nearly 28 million persons filed new claims for unemployment benefits over the six-week period ending April 25.1 The U.S. economy shrank at an annualized rate of 4.8 percent in the first quarter of 2020, and many analysts project it will shrink at a rate of $25 \%$ or more in the second quarter.2 Yet, even as much of the economy is shuttered, some firms are expanding in response to pandemic-induced demand shifts. As the Wall Street Journal put it, "The coronavirus pandemic is forcing the fastest reallocation of labor since World War II, with companies and governments mobilizing an army of idled workers into new activities that are urgently needed."3 In other words, Covid-19 is also a major reallocation shock.

We develop evidence on the extent and character of this reallocation shock for the U.S. economy. We start with anecdotal evidence, drawing on news reports and other sources. Anecdotal evidence is useful for its immediacy, as a source of hypotheses, and for insights into broader forces. Next, we turn to the Survey of Business Uncertainty (SBU) to construct novel, forward-looking measures of expected sales and job reallocation across American firms at a oneyear look-ahead horizon. The SBU is a monthly panel survey developed and fielded by the Federal Reserve Bank of Atlanta in cooperation with Chicago Booth and Stanford.

We use firm-level employment forecasts in the SBU to calculate the following quantity: the gross expected job gains at firms that anticipate growing over the next year plus the gross expected job losses at firms that anticipate shrinking minus the absolute value of the net change obtained by summing over all the forecasts. We activity weight the firm-level forecasts in this calculation and divide by aggregate employment to obtain the expected excess job reallocation rate at a one-year look-ahead horizon. This statistic quantifies the volume of cross-firm job

1 The unemployment claims data are available at https://oui.doleta.gov/unemploy/claims_arch.asp. 2 As of 31 March, Goldman Sachs projects that U.S. GDP will fall 34 percent (annualized) in the second quarter of 2020 (Carew, 2020). Baker, Bloom, Davis and Terry (2020) obtain a similar figure using the estimates implied by an empirical model of disaster effects that Baker, Bloom and Terry (2020) fit to historical data for 38 countries. According to Blue Chip Economic Indicators report of 10 April 2020, the mean forecast for U.S. GDP is a 24.5 percent (annualized) drop in the second quarter of 2020.

3 The quotation is from Bender and Dalton (2020). 
reallocation in excess of the amount needed to accommodate the aggregate net change. It is the forward-looking analog to the backward-looking measures of excess job reallocation examined in Dunne, Roberts and Samuelson (1989) and Davis and Haltiwanger (1992).4

Our measure of the expected excess job reallocation rate rises from 1.5 percent of employment in January 2020 to 5.4 percent in April. The April value is 2.4 times the pre-COVID average and is, by far, the highest value in the short history of the series. We also use firm-level sales forecasts in the SBU to compute the expected excess sales reallocation rate at a one-year forecast horizon. Expected sales reallocation shows a similar time-series pattern, reaching values from March to June that are four-to-six times the pre-pandemic average. Thus, our expected excess reallocation rate measures support the view that COVID-19 is a major reallocation shock.

We also quantify the near-term reallocative impact of pandemic-related developments on business staffing. For this purpose, we draw on two special questions fielded in the April 2020 SBU. One question asks (as of mid-April) about the coronavirus impact on own-company staffing since 1 March 2020, and another asks about the anticipated impact over the ensuing four weeks. Cumulating responses over firms and across these two questions, the data say that pandemicrelated developments caused near-term layoffs equal to 12.8 percent of March 1 employment and new hires equal to 3.8 percent. In other words, the COVID-19 shock caused 3 new hires in the near term for every 10 layoffs. Similarly, the Job Openings and Labor Turnover Survey (JOLTS) reports more than 4 hires for every 10 layoffs in March and April. These sizable new hires amidst a tremendous overall contraction align well with our anecdotal evidence of large pandemicinduced increases in demand at certain firms. ADP statistics in Cajner et al. (2020) and Census Bureau statistics on gross business formation also point to high rates of job creation and gross hiring activity, even in the near-term wake of the pandemic.

4 Many later studies consider backward-looking job reallocation measures. See Davis and Haltiwanger (1999) for a review. For applications of analogous backward-looking reallocation measures to other outcomes, see Dell'Ariccia and Garibaldi (2005) and Craig and Haubrich (2013) on bank lending, Eisfeldt and Rampini (2006) on physical capital, Davis et al. (2009) on sales, Broda and Weinstein (2010) on consumer products, Iacovone and Jovorcik (2010) on export products, Herrera, Kolar and Minetti (2011) on business credit, and Afonso and Lagos (2015) on the federal funds market. 
Next, we draw on special questions put to firms in the May 2020 SBU to quantify the anticipated shift to working from home after the coronavirus pandemic ends, relative to the situation that prevailed before the pandemic. To do so, we first ask firms about the share of full work days performed at home by their full-time employees in 2019. (Responses to this question for the pre-pandemic situation align well with worker responses to similar questions about working from home in the 2017-18 American Time Use Survey.) We also ask firms about the share of full work days performed at home that they anticipate for their full-time employees after the pandemic is over. Comparing response to the before and after question, we find that full work days performed at home will triple in the post-pandemic economy. This tripling will involve shifting one-tenth of all full work days from business premises to residences (and one-fifth for office workers). Since the scope for working from home rises with worker earnings, the shift in worker spending power from business districts to locations nearer residences is even greater.

Finally, we consider time-series evidence on the dispersion in monthly equity returns across U.S.-listed firms. Return dispersion relates less directly to future reallocation activity, but its availability over several decades helps us put the COVID-19 episode in perspective. Whether measured by the interquartile range or the standard deviation of returns in the value-weighted distribution, the dispersion in equity returns jumps sharply in March 2020, reaching levels last seen during the financial crisis of 2008-09 and the dot.com bust of the early 2000s. These three episodes exhibit the highest return dispersion in our sample period, which starts in 1984.

After presenting the evidence, we consider implications for the economic outlook and for policy responses to the pandemic. Even if medical advances or natural forces bring an early end to the health crisis, pandemic-induced shifts in working arrangements, consumer spending patterns, and business practices will not fully reverse for several reasons. First, more than half of all employees in the United States were working from home as of May 2020. These employees and their organizations have, of necessity, learned how to more effectively work and interact remotely. This type of learning by doing is a source of persistence in new working arrangements. Second, millions of households have tried online shopping and delivery services in recent months, and many will continue to value the convenience and (perceived) safety. Third, after turning to virtual meetings out of necessity, many businesses will find they offer an easier, cheaper alternative to travel and in-person meetings. Fourth, spurred by the pandemic, businesses 
and other organizations are undertaking investments in equipment, infrastructure and platforms that raise employee effectiveness when working remotely or engaging customers virtually. Fifth, also spurred by the pandemic, leading technology companies plan to intensify efforts to develop new products that improve the effectiveness of remote interactivity. Sixth, the pandemic has knocked down regulations that had inhibited a shift from in-person to virtual interactions, especially in the delivery of healthcare services.

Thus, much of the near-term reallocative impact of the pandemic will also persist, as indicated by our forward-looking reallocation measures and our evidence on the shift to working from home. Drawing on special questions in the April SBU and historical evidence of how layoffs relate to realized recalls, we project that 32 to 42 percent of COVID-induced layoffs will be permanent. We also construct projections for the permanent-layoff share of recent job losses from other sources, obtaining similar results.

Historically, creation responses to major reallocation shocks lag the destruction responses by a year or more. Partly for this reason, we anticipate a drawn-out economic recovery from the COVID-19 shock, even if the pandemic is largely controlled within a few months. Multiple forces contribute to delayed creation, as we discuss. Policy responses to major shocks and inherited features of the policy landscape can further stretch out the creation response, slowing the recovery. In this regard, we discuss four aspects of U.S. policy that retard creation responses to the pandemic-induced reallocation shock: Unemployment benefit levels that exceed earnings for many American workers under the Coronavirus Aid, Relief, and Economic Security (CARES) Act, policies that subsidize employee retention irrespective of the employer's longer term outlook, land-use restrictions that inhibit the reallocation of jobs and workers, occupational licensing restrictions the impede mobility across occupations and states, and regulations that inhibit business formation and expansion.

\section{Anecdotal Evidence}

\section{a. Hiring and job reallocation}

Recent news stories highlight the millions of layoffs triggered by the pandemic and lockdown. They also recount many examples of large-scale hiring. Walmart has hired 235,000 new employees since mid-March and plans to convert many of them to permanent positions. 
Amazon has hired 175,000 new employees since March and plans to convert more than 70 percent of them to permanent positions (Herrera, 2020). Dollar General aimed to hire 50,000 new workers by the end of April.5 Lowe's, the home improvement chain, aimed to hire 30,000 new employees this spring (Tyko, 2020). As of late March, many takeout and delivery-oriented firms were scrambling to hire workers. Instacart, for example, added 300,000 shoppers to its payroll, and Domino's added 10,000 pizza delivery drivers (Bender and Dalton, 2020). Papa John's sought 20,000 new employees to meet heightened demand for pizza delivery (Bandolm, 2020). Outschool sought to hire 5,000 new teachers in the last two weeks of March to offer more online classes in light of school closures.6 Beyond the massive increase in shipping, delivery and warehouse staff, there are large surges in demand for contact tracers, thermal monitors, socialdistancing monitors, and decontamination technicians (Green and Matthews, 2020).

Stafford et al. (2020) describe how COVID-induced "changes to the way people everywhere work, talk, eat and shop "led to explosive growth at six companies: MarketAxess, an electronic bond trading platform saw large increases in trading volume and its stock market value; Discord, a gaming-orienting messaging app, has morphed into a home school aid; Nissin Foods, a producer of instant noodles with 36 factories in 16 countries, has enjoyed large gains in sales and profitability; FRP Advisory, which advises firms on restructuring, has experienced a quadrupling of client numbers; customer orders at Berlin-based Delivery Hero doubled from a year earlier, leading the firm to open dozens of its own kitchens to service its delivery operations; retail sales at Lavazza, the Italian coffee firm, grew 15 percent globally and 10 percent in Italy during the first four months of 2020 as compared to 2019. A recent Financial Times report (2020) identifies the 100 publicly listed companies with the largest market capitalization gains in 2020 and briefly explains how pandemic-induced shifts are benefiting each company. Heading the list are Amazon, Microsoft, Apple, Tesla, Tencent, Facebook, Nvidia, Alphabet, PayPal and T-Mobile. Other companies on the list include Netflix, Shopify, Zoom Video, Adobe, Abbvie, Alibaba, Home Depot, Roche and Regeneron Pharmaceuticals.

5 See https://careers.dollargeneral.com. Accessed on 19 April 2020.

6 See https://blog.outschool.com/outschool-needs-5-000-teachers-to-start-offering-live-online-classesoutschool-needs-5-000-teachers-to-start-offering-live-online-classes-in-the-next-2-weeks/. Accessed on 19 April 2020. 
Some companies formed partnerships that exploit the reallocative nature of the COVID19 shock to speed hiring. Supermarket chain Kroger created an exchange with Sodexo, Sysco and Marriott International to hire workers laid off from food-service and hospitality firms. CVS Healthcare sought to recruit 50,000 new staff by partnering with the Hilton hotel chain, clothing retailer Gap, and Delta Airlines (Weber, 2020). Uber now lists job openings at 7-Eleven, Amazon and McDonald's and a dozen other companies for its unemployed drivers (Lee, 2020a).

The near-term reallocative effects of the COVID-19 shock are also evident in consumer spending patterns. Earnest Research, a data analytics firms, tracked credit and debit card purchases for nearly six million Americans to assess the impact of the COVID-19 shock on consumer spending. For the week ending 1 April 2020, their data show that spending on airlines, hotels, rental cars, taxis, ride sharing and movie theaters was down 75-95 percent relative to spending in 2019 (Leatherby and Gelles, 2020). Spending on fast food, auto parts, and autos was down 35 percent, and spending on apparel was down 70 percent. At the same time, spending on home improvement, video streaming, gaming, food delivery, and online grocers boomed.

\section{b. Intra-Industry Reallocation}

Perhaps because we often conceptualize the economy in terms of industries and regions, one might guess that pandemic-induced reallocation will mainly involve cross-industry and cross-region shifts. A large body of evidence suggests otherwise. Idiosyncratic, employerspecific factors dominate gross job creation and destruction, while employment shifts between industries and regions account for only a small share of job reallocation. For example, when Davis and Haltiwanger (1992) split the U.S. manufacturing sector into about 450 four-digit Standard Industrial Classifications, between-industry shifts account for only 13 percent of annual excess job reallocation during the 1970s and 1980s. When they split manufacturing into roughly a thousand groups defined by the cross product of states and two-digit SICs, between-group shifts account for only 14 percent of excess job reallocation. This type of finding has been 
replicated many times across countries, sectors and time periods.7 Hence, we expect the bulk of the pandemic-induced reallocation response to occur within industries and regions.

The restaurant industry provides a salient example of intra-industry reallocation in the current crisis. A survey by the National Restaurant Association in late March finds that 3 percent of restaurant owners and operators had permanently closed in response to COVID-19, and another 11 percent expected to close permanently in the next 30 days (Taylor, 2020). Applying these figures to the number of U.S. restaurants yields more than 100,000 permanent restaurant closures in the near-term wake of the COVID-19 shock. At the same time, takeout and deliveryoriented chains are experiencing a huge demand boom, as illustrated by the anecdotes for Domino’s Pizza and Papa John's. Much of this immediate reallocative impact will likely persist.

Turning to another salient example, an unsettled economy and uncertain outlook favor large incumbents with deep pockets (Mims, 2020). As Cutter and Thomas (2020) write:

The biggest players in tech are hoovering up talent in the midst of the coronavirus pandemic. As some of Silicon Valley's most-promising startups lay off workers and others freeze hiring, established companies including Apple Inc., Alphabet Inc.'s Google and Amazon.com Inc. are pursuing software engineers, data scientists, product designers and others. Facebook Inc. says usage has spiked during the coronavirus crisis and it is committed to policing platforms ahead of the 2020 presidential election, so it will hire more than 10,000 people this year for critical roles on its product and engineering teams. The current moment may give well-capitalized tech companies a chance to poach skilled workers who until recently were gravitating to smaller upstarts, veteran technology recruiters say.

These remarks suggest that the pandemic will induce a reallocation from smaller, younger tech firms to larger, established ones. A similar dynamic may play out in other industries as incumbents with deep pockets and established markets attract workers with newly-heightened concerns about job security.

A third example highlights the role of new-found concerns about face-to-face interactions. Before the pandemic, Medicare and Medicaid regulations largely precluded doctors, nurse practitioners, clinical psychologists and licensed social workers from reimbursement for

7 Davis and Haltiwanger (1999, Table 5) review evidence from studies that span thirteen countries. Employment shifts between regions and industries account for less than 10 percent of excess job reallocation in half the studies and 10 to 20 percent in the rest. 
patient services provided in virtual consultations. These regulations were cast aside during the pandemic, unleashing a flood of virtual consultations and surging interest in "telemedicine." 8 In a recent article in Medical Economics, a publication aimed at healthcare professionals and business managers, Mann (2020) remarks that telemedicine works "for most medication refills ... urinary tract infections, colds and rashes, diabetes and hypertension follow-ups, lab results, post-op visits, birth control and fertility, and mental health." While a pandemic-induced shift to telemedicine may have little impact on the net demand for medical services, some physician practices and medical clinics will respond adroitly to the shift, and many will not. Horn (2020) offers an insightful glimpse into the commercial challenges presented by a partial shift to telemedicine. As his discussion suggests, there is high potential for a reallocation of customers, revenues and workers across practices and clinics. A similar dynamic will play out in other professional, business, and personal services: Some businesses will respond deftly to newlyintensified customer concerns about face-to-face interactions, and many will not.

A fourth example pertains to the grocery business and general retail. Concerns about face-to-face interactions have stimulated huge increases in the demand for online grocery shopping and delivery services. As of May 2020, online U.S. grocery sales are up an estimated 450 percent from August 2019 and 24 percent from April 2020.9 One-third of U.S. households used online grocery shopping services in May 2020, more than double pre-pandemic projections for the month. Many large retailers, including Whole Foods, have hired new staff and reconfigured stores to meet the growing demand for online shopping. Walmart is testing new technology to autonomously select items from a store room, pack them, and prepare them for pickup or delivery. Amazon is experimenting with robot-powered fulfillment centers for online orders. These capacity expansions and investments in new technologies suggest that retailers see the pandemic as driving a persistent shift from traditional shopping modes to online shopping. Amazon, Walmart and some other retailers are well positioned to respond to this shift. Many other retailers are not. So, a large shift in shopping modes also means a reallocation of jobs and workers across firms. This process is already well underway, as indicated by a wave of recent

8 For a description of these regulatory changes, see the announcements by the Centers for Medicare \& Medicaid Services at www.cms.gov/newsroom.

9 This and other factual claims in this paragraph are based on Lee (2020b). 
bankruptcies and massive downsizings at J.C. Penney (general merchandise), J.Crew (apparel), Nieman Marcus (luxury retailer), Pier 1 (imported household goods), Stage Stores (department stores), and Victoria's Secret (lingerie) (Kapner, 2020ab).

There are also well-documented examples of major past structural transformations that took the form of intra-industry reallocation. Foster, Haltiwanger and Krizan (2006) attribute large productivity gains in the U.S. retail sector in the 1990s mainly to a reallocation from small retail outlets to larger, more productive stores operated by national chains. Walmart, Target, Home Depot, Staples, Barnes \& Noble and Best Buy played significant roles in this process, expanding at the expense of rivals. Later, the rise of online shopping brought another major reallocation. In this regard, it's worth recalling that Amazon began as an online bookseller, eventually displacing rival booksellers who shifted online too little or too late. The coronavirus pandemic is accelerating the shift to online shopping.

\section{Systematic Evidence}

\section{a. Constructing Forward-Looking Reallocation Measures}

We construct forward-looking reallocation measures using data from the Survey of Business Uncertainty (SBU), which samples senior executives in American firms at a monthly frequency. The SBU covers all 50 states, every major nonfarm industry, and a range of firm sizes. Core survey questions elicit subjective forecast distributions over own-firm future outcomes at a one-year look-ahead horizon. (More precisely, the look-ahead horizon is twelve months for employment and four quarters for sales.) The survey instrument also gathers data for current and past outcomes. See Altig, Barrero et al. (2020c) for more information.

Let $\mathrm{E}_{t} L_{i, t+12}$ denote the expected level of employment in month $t+12$ at firm $i$ implied by its subjective forecast distribution at $t$. Define the corresponding month- $t$ expected employment growth rate at a 12-month look-ahead horizon as the arc percentage change, 10

10 This growth rate measure is symmetric about zero, bounded between -2 and 2 , and equal to log changes up to a second-order Taylor series approximation. Growth rates computed in this manner aggregate exactly when combined with suitable weights, given by the simple mean of initial and (expected) terminal levels. 


$$
\mathrm{E}_{t} g_{i, t+12}=\frac{\mathrm{E}_{t} L_{i, t+12}-L_{i t}}{0.5\left(L_{i t}+\mathrm{E}_{t} L_{i, t+12}\right)}
$$

where all quantities on the right side derive from survey responses in month $t$. Denote the firm's activity weight as $z_{i t} \equiv 0.5\left(L_{i t}+\mathrm{E}_{t} L_{i, t+12}\right)$ and aggregate activity as $Z_{t}=\sum_{i} z_{i t}$. Let $\mathcal{S}_{t}^{+}$and $\mathcal{S}_{t}^{-}$denote the sets of firms at $t$ with positive and negative values, respectively, for $\mathrm{E}_{t} g_{i, t+12}$.

We compute the expected excess job reallocation rate in month $t$ as

$$
\mathrm{E}_{t} X_{t+12}^{\mathrm{jobs}}=\sum_{i \in \mathcal{S}_{t}^{-}}\left(\frac{Z_{i t}}{Z_{t}}\right)\left|\mathrm{E}_{t} g_{i, t+12}\right|+\sum_{i \in \mathcal{S}_{t}^{+}}\left(\frac{Z_{i t}}{Z_{t}}\right) \mathrm{E}_{t} g_{i, t+12}-\left|\sum_{i}\left(\frac{Z_{i t}}{Z_{t}}\right) \mathrm{E}_{t} g_{i, t+12}\right|,
$$

where the first term on the right side is the expected gross job destruction rate over the 12-month forecast horizon, the second term is the expected gross job creation rate, and the third term is the absolute value of the expected net employment growth rate.11 We compute the expected excess sales reallocation rate at a four-quarter forecast horizon in an analogous manner.12

Since we use SBU data to construct our forward-looking reallocation measures, we would like some assurance that the underlying firm-level data contain meaningful forecasts. In this regard, Altig, Barrero et al. (2020c) and Barrero (2020) show that firm-level growth rate expectations in the SBU data are highly predictive of realized growth rates. Moreover, firm-level subjective uncertainty measures in the SBU response are highly predictive of the magnitudes of firms' forecast errors and future forecast revisions. Using survey questions with the same design as the SBU questions, a revision underway of Bloom et al. (2017) finds that plant-level growth rate expectations in the Census Bureau's Manufacturing and Organizational Practices Survey are

This approach to growth rate measurement and aggregation has become standard in the literature on business-level dynamics. See Davis and Haltiwanger (1999).

11 In practice, we winsorize the $z_{i t}$ values at 500 and the $\mathrm{E}_{t} g_{i, t+12}$ values at the $1_{\text {st }}$ and $99_{\text {th }}$ percentiles of the distribution of expected employment growth rates in data pooled over the period from October 2014 to December 2018. These thresholds follow Altig, Barro et al. (2020c).

12 For sales, we winsorize $z_{i t}$ at the $90_{\text {th }}$ percentile of its distribution in the pooled sample from September 2016 to April 2020. We winsorize $\mathrm{E}_{t} g_{i, t+12}$ at the $1_{\mathrm{st}}$ and $99_{\text {th }}$ percentiles of the distribution of expected sales growth rates in the pooled sample for the period from October 2014 to December 2018. See Altig, Barrero et al. (2020c) for an explanation of how we obtain arc percentage changes and implied levels of expected future sales from SBU data on the forecast distribution over future sales growth rates. 
also highly predictive of realized outcomes. These studies give us confidence that our forwardlooking reallocation measures reflect meaningful forecasts of firm-level growth rates.

That said, there are good reasons to think that our SBU-derived measures understate the expected reallocation rate on average, and that they also understate the rise in expected reallocation activity in the wake of the pandemic. First, the SBU under samples younger firms, which have much higher reallocation rates than mature firms. See Altig, Barrero et al. (2020c) for additional discussion and references to the relevant literature. Second, highly stressed firms are less likely to respond to surveys, which leads to an understatement of expected destruction activity.13 Third, we cannot sample firms that will enter in the future, which causes an understatement of expected creation activity. Thus, we regard our estimates of forward-looking reallocation rates as conservative in terms of both average levels and the pandemic-induced response.

\section{b. Expected Excess Reallocation Rates}

Table 1 reports average expected growth rates and excess reallocation rates from September 2016 to January 2020, before the Covid-19 pandemic impacted the U.S. economy.14 The expected excess reallocation rate averages 0.97 percent for sales and 2.23 percent for jobs. Figure 1 displays the expected excess job reallocation rate from October 2016 to May 2020. It rises from 1.54 percent in January 2020 to 5.39 percent in April, which is 2.4 times the pre-COVID mean. The upward jump from March to April is the largest move in the short history of the series. Figure 2 shows a similar pattern for the expected sales reallocation rate, which jumps from 0.24 percent in January 2020 to 4.08 percent in March and above 6 percent in May. The March, April and May values are also the highest in the history of the series, and several times the pre-COVID mean. In sum, our forward-looking relocation measures confirm that the COVID-19 pandemic is a large reallocation shock.

13 In line with this remark, the survey response rates among active SBU panelists are 57\% in January 2020 $60 \%$ in February, 57\% in March and 52\% in April, where "active" panelists are those who responded to the survey at least once in the previous six months. 14 The SBU first went to field in October 2014, but the early monthly samples were small and our formulation of the look-ahead questions did not stabilize until September 2016. 
Several other countries conduct surveys that could be used to construct forward-looking reallocation measures like the ones shown in Figures 1 and 2. The U.K. Decision Maker Panel, a monthly survey that began in August 2016, includes questions patterned after the ones in the SBU (Bloom et al., 2018). Surveys in Germany, Italy and Japan also collect data on the expectations of firm-level variables. See Guiso and Parigi (1999), Bachmann and Elstner (2015), Bachman et al. (2018), Massenot and Pettinichi (2018), Tanaka et al. (2019) and Chen et al. (2019). Thus, it is feasible to construct forward-looking excess reallocation time series for several countries, which would be quite helpful in evaluating their predictive content and usefulness for policy makers.

\section{c. Expected Growth Rates in the Wake of the Pandemic}

Figures 1 and 2 also show the monthly paths of expected employment and sales growth rates for the period covered by the SBU. Expected twelve-month employment growth fell about 3.4 percentage points from February to May 2020, and expected sales growth fell about 7.3 percentage points from February to April. While these statistics point to a sharp deterioration in the U.S. economic outlook in the wake of the COVID-19 shock, they are milder than some projections. One possibility is that SBU firms expect a very large near-term hit from the pandemic and lockdown in 2020 and a substantial, but partial recovery by April 2021.

To investigate that possibility, we turn to a special question fielded as part of the April 2020 SBU. The question reads as follows: "What is your best guess for the impact of coronavirus developments on your firm's sales revenue in 2020?" The response options are a respondentsupplied percentage amount, up or down, and no effect. The results, summarized in Table 2, say that firms expect the coronavirus pandemic to lower their sales by $18-19$ percent in 2020 . This is an enormous negative shock, and it is more than twice as large as the fall from January to April 2020 in the average one-year sales forecast. Taken together, the evidence in Table 2 and Figure 2 says that firms in the SBU anticipate a huge negative shock to their sales in 2020 followed by a considerable but highly incomplete bounce back by April-June 2021.

\section{d. Gross Hiring and Business Formation in the Pandemic's Immediate Wake}

The top part of Table 3 presents two questions about the impact of COVID-19 on staffing levels that appeared in the April 2020 SBU. One question asks about impact on own-company staffing levels since 1 March 2020, and the other asks about the anticipated impact over the next 
four weeks. For each question, the survey instrument allows responses in five categories: number of permanent layoffs, with no expectation of recall; number of temporary layoffs and furloughs; hires of new employees; cuts to the number of contractors and leased workers; and additions to the number of contractors and leased workers. Cumulating the responses to these two questions and aggregating over firms yields a near-term net contraction (exclusive of quits) equal to 10.8 percent of March 1 employment.15 92 percent of this net contraction happened between March 1 and the mid-April survey response period, and the rest is anticipated to happen over the ensuing four weeks. Using JOLTS statistics to impute quits, we obtain a net staffing reduction equal to 13.7 percent of March 1 employment, which is very similar to the fall in active employment among continuing firms that Cajner et al. (2020, Figure 2.B) find over the same time period in tabulations of ADP payroll records.

Despite the large negative employment impact of the pandemic and lockdown, the coronavirus shock caused sizable gross staffing gains over the span of two and one-half months: new hires equal to 3.8 percent of March 1 employment, and new contractors and leased workers equal to 0.2 percent. SBU data also say the COVID shock caused gross staffing reductions equal to 14.9 percent of March 1 employment (17.8 percent inclusive of quits), mostly due to temporary layoffs and furloughs.16 Echoing our remarks in Section II.a, the under sampling of young firms in the SBU, the omission of new firms from our sample frame, and the lower response rates of highly stressed firms are reasons to think our estimates of gross staffing changes are downwardly biased.

15 Bartik et al. (2020) find a 40 percent employment contraction from 31 January to late March/early April in their survey of American firms with fewer than 500 employees. The gap between their employment contraction figure and ours is partly due to their focus on small firms. As they report in their Table 2, smaller firms in their sample contract more sharply in this period. We also find sharper contractions among the smallest firms in the SBU. However, the firm-size differential is too small to fully explain the discrepancy between their estimated employment contraction and ours. 16 We can obtain a corresponding estimate of aggregate gross staffing reductions in the private sector as follows: There were 152.5 million employees in the nonfarm private sector as of February 2020, according to the BLS Current Employment Statistics. According to BLS (2017), independent contractors are 6.9 percent of employment in the Current Population Survey. Multiplying the February 2020 CPS employment figure by 6.9 percent yields an estimated 10.9 million contract workers. Finally, $17.8 \%$ of $163.4(=152.5+10.9)$ million yields aggregate gross staffing reductions of 28.4 million. 
We can restate our results about gross staffing gains and losses in terms that are less sensitive to these sources of bias. In particular, Table 3 implies that coronavirus-related developments caused about 3 new hires for every 10 layoffs. If we include contactors and leased workers, the ratio is about 2.7 gross staffing gains for every 10 gross staffing reductions. JOLTS data for March and April show 4.3 hires for every 10 layoffs.17 Similarly, Cajner et al. (2020) find a high incidence of new hires in ADP data for April and May 2020. While it might seem surprising to find so many hires amidst the sharpest employment contraction since records began, simultaneous large-scale hiring and separations are a ubiquitous feature of U.S. labor markets. See, for example, Davis, Faberman and Haltiwanger (2006) and Lazear and Spletzer (2012).

JOLTS data on job openings also point to large-scale hiring plans in the immediate wake of the COVID-19 pandemic. There were about 6.2 million job openings in the U.S. private sector on the last (business) day of January and February 2020, 5.3 million on the last day of March, and 4.4 million on the last day of April. In other words, job openings after the pandemic struck were about 71 to 85 percent as large as before it struck. In this regard, it's important to note that the JOLTS concept of job openings excludes positions open only to internal transfers, positions to be filled by recalls from temporary layoffs, and positions that are not available to start within 30 days. According to JOLTS data, actual hires in April 2020 were 60 percent of actual hires in February. Thus, JOLTS statistics confirm that large-scale hiring activity, actual and planned, have continued during the pandemic recession, though at a much-reduced pace.

Census Bureau statistics on gross business formation also point to gross hiring activity in the near-term wake of the pandemic, again at a slower pace than pre-COVID. These statistics derive from administrative data on applications for a new Employer Identification Number (EIN) on IRS Form SS-4. Figure 3 reports statistics for "high-propensity" applications, which are the subset of applications for a new EIN that the Census Bureau regards as having a high propensity

17 The JOLTS sample is much larger than the SBU sample, and presumably more representative of the U.S. private sector. SBU-based statistics are available much earlier, which is a major advantage in the wake of a huge and atypical shock. We first reported Table 3 on 1 May in Altig, Barrero et al., (2020b), while the JOLTS-based statistics for April were first reported on 9 June. Note that the two surveys also ask somewhat different questions: The SBU asks explicitly about the causal impact of COVID-19 developments. In contrast, the JOLTS askes about all hires and separations, regardless of cause. 
to hire paid employees. The figure makes three points. First, gross business formation rates in the second half of March and throughout April are down 20 to 38 percent relative to the same week in the 2019. Second, and perhaps surprisingly, high-propensity business applications continue at the pace of 20-30 thousand per week. While depressed, business formation did not dry up in the immediate wake of the COVID-19 shock. Third, new business applications began to recover in May and by the end of May were down less than five percent from a year earlier. In sum, new business formation was greatly depressed, but not moribund, in the wake of the COVID-19 shock, and it has mostly recovered from its post-pandemic lows.

The statistical evidence in Table 3 and Figure 3 align well with the anecdotal evidence in Section I of large pandemic-induced demand increases at certain firms, even as layoffs in the U.S. economy exceeded thirty million. At the risk of belaboring the obvious, it's also worth remarking on an important distinction between the evidence in Table 3 and Figure 3, on the one hand, and Figures 1 and 2 on the other. Table 3 speaks to the near-term reallocative impact of the COVID-19 shock, and Figure 3 provides evidence that job-creating business formation continues in the face of the pandemic and lockdown. In contrast, Figures 1 and 2 provide evidence that the shock is expected to trigger unusually large rates of job and sales reallocation across firms over the next year. Thus, our evidence speaks to both near-term and medium-term reallocative effects of the COVID-19 shock.

\section{e. The Shift to Working from Home}

COVID-19 has led to a huge social experiment in working from home. To quantify this phenomenon, we surveyed 2,500 U.S. residents aged 20-64 who earned more than $\$ 20,000$ in 2019. Figure 4 summarizes their current work status as of late May 2020 based on responses to the following question: “Currently (this week) what is your work status?” Response options are "Working on my business premises," "Working from home," and other options that Figure 4 groups under "Not working." Nearly 42 percent of our 2,500 respondents report working from home (50 percent on an earnings-weighted basis). Adjusting for those not working, our survey results say that 62 percent of labor services were supplied from home as of late May (67 percent on an earning-weighted basis). In an independently conducted survey, Brynjolfsson et al. (2020) 
find that 50 percent of employed persons were working from home as of early May. Both surveys confirm that COVID-19 has triggered a massive shift to working from home.

Anecdotal accounts and economic reasoning suggest that much of this shift will persist. For example, Horwitz (2020) reports that Facebook will move to a "substantially remote workforce over the next decade" in response to the "dispersed structure that the coronavirus pandemic forced on it." Facebook foresees a gradual shift to working from home, because it "will require new techniques and tools to compensate for the loss of in-person office interactions." Given its success in creating platforms and tools for remote interactivity, Facebook's efforts to develop better tools for remote worker interactions are likely to have an outsized impact on the overall extent of working from home.

A large, permanent shift to working from home would have powerful effects on the spatial distributions of jobs, labor supply, and worker spending, with profound implications for the future of cities. Motivated by these considerations, we posed two questions in the mid-May SBU to assess how firms expect COVID-19 to change the extent of working from home after the pandemic recedes. To get a pre-pandemic starting point, we asked "What percentage of your fulltime employees worked from home in 2019?" And, to gauge the post-pandemic situation, we asked "What percentage of your full-time employees will work from home after the coronavirus pandemic?" For each question, we let firms sort their full-time employees into five categories, ranging from the share that works from home five full days per week to the share that rarely or never works from home.

Table 4 summarizes the employment-weighted survey responses by firms as well as worker responses to a similar question in the 2017-18 American Time Use Survey (ATUS). The firm-side SBU and worker-side ATUS yield quite similar pre-COVID results. Both surveys say 90 percent of employees rarely or never worked from home, and a very small fraction worked from home five full days per week.18 As reported in the rightmost column, about 5 to 6 percent

18 For SBU industry sectors that we can match directly to ATUS statistics, the two data sources imply a similar incidence of working from home before COVID-19. For manufacturing, SBU data say 9 percent of employees worked at home at least one day a week prior to COVID-19, and the ATUS data that 7.3 percent did so. For retail and wholesale trade, the corresponding figures are 4.1 percent and 4.0 percent, respectively. 
of full working days were performed at home before the pandemic hit. According to the SBU results, the anticipated share of full working days at home is set to triple after the pandemic ends - rising from 5.5 percent to 16.6 percent of all working days. Put differently, more than one-tenth of full work days will shift from business premises to residences. The implied spatial shift in worker spending is greater yet, because the scope for working from home is strongly positively correlated with earnings (Dingel and Nieman, 2020).

As reported in Table 5, firms in every sector anticipate a large shift to working from home. Consider Finance, Insurance, Professional Services and Business Services, industries that disproportionately employ well-paid office workers in city business districts. Firms in this sector anticipate that full work days at home by full-time employees will rise from 10.7 percent of all work days before the pandemic to 29.2 percent after the pandemic. These figures say that 21 percent of full work days performed on business premises before COVID-19 will switch to working from home.19 This statistic implies a huge, persistent shift in worker spending power away from central business districts to locations closer to residences.

\section{f. Dispersion in Equity Returns Across Firms}

Tables 1-5 and Figures 1-4 draw on data sources with short histories, which makes it hard to situate the evidence in a broad historical context. Thus, we turn to time-series evidence on the dispersion of returns across the common equity securities of U.S.-listed firms.20 Specifically, we compute the interquartile range and the standard deviation of value-weighted returns across firms using closing market prices from the end of one month to the end of the next. We consider return dispersion rather than the excess reallocation of equity value given the predominant role of discount rate variation in aggregate stock market moves (e.g., Shiller, 1981, Campbell and Shiller, 1988, and Cochrane, 2011). If discount rates on risky securities generally rose in reaction to the COVID-19 shock, an excess reallocation measure would obscure heterogeneity in the

19 Calculated as 100 times $(29.2-10.7) /(100-10.7)$.

$20 \mathrm{We}$ are hardly the first to use the dispersion in stock returns as a proxy for reallocative shocks. See, for example, Loungani, Rush and Tave (1990), Brainard and Cutler (1993) and Davis, Loungani and Mahidhara (1997). Unlike these earlier works, which focus on cross-industry return dispersion, we consider the dispersion in value-weighted returns across firms. 
shock's impact on expected firm-level cash flows.21 In contrast, this heterogeneity shows up in return dispersion measures if the discount rate variation itself is dominated by common factors.

Figure 5 displays the dispersion in monthly equity returns from January 1984 to April 2020. Three episodes stand out: the dot-com market bust in the early 2000s, the financial crisis of 2008-2009, and the market's reaction to the COVID-19 shock in March 2020. The first two episodes involve high return dispersion for more than a year and multiple peaks. It remains to be seen whether the same pattern will play out this time. Nevertheless, Figure 5 suggests that the COVID-19 shock triggered unusually large differences across firms in shocks to their expected future cash flows. That is, the stock return data support the view that the COVID-19 shock had large reallocative effects among publicly traded firms. When we consider the one-month interval from 24 February to 21 March, the impact of the COVID-19 shock on the dispersion in returns is greater yet, as shown by the large dots in Figure 5.22

Several recent studies provide evidence on the sources of heterogeneity in the COVID-19 impact on listed firms. Hassan et al. (2020) characterize and quantify the concerns that senior executives express in corporate earnings conference calls. As the pandemic spread from January to March, executives voiced growing concerns about negative demand shifts, rising uncertainty, supply chain disruptions, capacity curtailments, and employee welfare. Davis, Hansen and Seminario (2020) and Ramelli and Wagner (2020) trace COVID-induced differences in firmlevel returns to differences in their exposures to global supply chains, exports to China, food and drug regulation, energy regulation, and financial regulation. Papanikolaou and Schmidt (2020) report daily equity returns in 2020 for firms sorted by the share of employees able to work remotely. From 14 February 2020 to 15 June, the cumulative return differential between the top and bottom quartiles is 19.4 percentage points, with the bulk of the return differential emerging by mid-March.23 Pagano et al. (2020) also find much higher returns in the wake of COVID-19 at

${ }_{21}$ Our supposition here on the rise in discount rates in reaction to the COVID-19 shock finds support in Gormsen and Koijen (2020).

22 We chose 24 February, because it is the first large daily move in the U.S. stock market that next-day journalistic accounts attribute to the COVID-19 pandemic. See Baker et al. (2020).

${ }_{23}$ See the third chart at https://sites.google.com/site/lawrencedwschmidt/covid19, accessed on 18 June. 14 February 14 is the baseline date in their chart, and 15 June is the most recent available date. 
firms that are "resilient" to social distancing requirements, as measured by ability to perform jobs at home and without interactions in physical proximity. Resilient firms also enjoyed strong relative returns from 2014 to 2019, suggesting that the COVID-19 shock reinforced shifts in the economy that began before the pandemic. This reinforcing aspect of the shock may further raise unemployment and slow its decline, as argued in Davis (1987). Finally, Pagano et al. provide evidence that investors continue to price pandemic-related risks into firm-level equity prices as of May 2020, suggesting they assign material probabilities to future pandemics.

\section{Implications for the Economic Outlook}

\section{a. Reasons to Anticipate a Slow Recovery}

As of 4 June, confirmed cases of COVID-19 exceed 6.7 million, with 395 thousand persons known to have died from the disease.24 The weekly death toll in the United States has drifted downward since late April, but there remains great uncertainty about the future course of the pandemic and the duration, extent and effectiveness of economic lockdowns and voluntary social distancing efforts. In particular, we do not know whether a gradual re-opening of the economy will lead to a major surge in new cases, prompting authorities to re-impose tight restrictions on commercial activity. Obviously, if the pandemic and partial shutdown linger, the economic recovery will be delayed. Thus, the future course of the pandemic and containment efforts could lead to a delayed or sluggish recovery. If global pandemics with serious health consequences become an oft-recurring phenomenon, they will undercut growth for many years.

Under an optimistic scenario, the pandemic recedes in the coming weeks and months, COVID-19 treatments improve, an effective vaccine becomes available and widely deployed within 12 months, and the economy gradually comes back on line over the next 2-3 months without serious setbacks. Even in this scenario, we see several reasons to anticipate a lengthy recovery. U.S. real GDP may not surpass its 2019 level until the latter half of 2021 or later, and the return path to full employment is likely to take even longer. We turn to the reasons now.

24 See the Johns Hopkins Coronavirus Resource Center at https://coronavirus.jhu.edu/map.html. 
The pandemic and lockdown will curtail current and near-term aggregate demand through several channels. First, labor incomes and profits are severely depressed and will remain so for some time. Second, economic uncertainty is extraordinarily elevated, which further depresses consumption expenditures and investment demand. Since uncertainties about the course of the pandemic and the stringency of social distancing measures are likely to abate in the coming weeks and months, firms have especially strong incentives to defer investments that are costly to reverse. Third, temporary disruptions on the supply side of the economy can cause aggregate demand to fall more than one-for-one with the direct impact of the supply shock (Guerrieri et al., 2020). Fourth, as we discuss momentarily, the COVID-19 shock has negative effects on the economy's productive potential in the future. That lowers expected future incomes, which further depresses current spending demands by forward-looking agents.

The overall fall in aggregate demand is massive. While policymakers have aggressively deploying fiscal and monetary tools to counter this fall, it seems unlikely that they will or can achieve a full offset. Thus, we expect demand-side forces to depress employment and output for several months or more.

We now turn to supply-side considerations, with a focus on developments that influence the economy's future productive potential. First, the cash-flow crunch caused by the lockdown, uncertainty about the future course of the pandemic, concerns about reduced incomes in the nearand medium-term, and uncertainty about the outlook for growth and product demand are all likely to depress capital investment for several months or more. Thus, the economy will carry a smaller stock of productive capital into the future as a consequence of the COVID-19 shock. In addition, pandemic-induced demand shifts and continuing concerns about infectious disease will undercut the production value of certain forms of capital such as large-scale entertainment venues, high-density retail facilities, and restaurants with closely-packed patrons.

Second, universities, government labs, and commercial facilities have shuttered non-COVID research projects. Schools have sent students home, and universities are making do with remote classes. Barrero, Bloom and Wright (2017) and Bansal et al. (2019) provide evidence that R\&D investments are highly sensitive to uncertainty, because they are irreversible and riskier than investments in physical capital. The same may hold for investments in worker training, strong 
managerial practices, and other forms of intangible capital. Given the extraordinarily high levels of economic uncertainty in the wake of the COVID-19 shock (Altig, Baker et al., 2020), investment rates in these intangibles are likely to be at least temporarily depressed. Immigration and trade, facilitators of innovation, have also shriveled. We expect these developments to lower the trajectory of future productivity into 2021 and beyond.

The third reason we anticipate a slow recovery on the supply side leads us back to the pandemic-induced reallocation shock and is the focus of the next section.

\section{b. Creation Lags Destruction in the Response to Reallocation Shocks}

Davis and Haltiwanger (2001) study the dynamic effects of oil price shocks in the 1970s and 1980s on job creation and destruction activity in the U.S. manufacturing sector. They find sizable reallocative effects of oil price shocks spread out over several years. A key message is that the destruction side of reallocation precedes the creation side by 1-2 years. Employment and output are depressed in the interim. Reasons for the delayed creation response include the time needed to plan new enterprises and business activities, the time required to navigate regulatory hurdles and permitting processes to start or expand businesses, time-to-build in capital formation, uncertainties that lead to delays in making sunk investments, and search and matching frictions in forming new relationships with suppliers, employees, distributors, and customers.

To appreciate why creation responses can lag months and years behind destruction responses, consider the experience of the American auto industry in the wake of the 1973 oil price shock.25 As Bresnahan and Ramey (1993) document, the shock increased the demand for small, fuel-efficient cars and simultaneously reduced the demand for larger cars. Capacity utilization and output fell in the wake of the oil price shock, even though a handful of plants equipped to produce small cars operated at peak capacity.

Several factors made it hard for the industry to respond rapidly to the increased demand for small, fuel-efficient cars. First, much of the physical capital in the U.S. auto industry was dedicated to the production of larger rather than smaller cars. Second, U.S. auto workers had accumulated skills that were specialized in the production of particular models, and these tended

25 This paragraph and the next borrow from Davis and Haltiwanger (2001). 
to be larger vehicles. Third, many auto workers laid off from large-car plants could not take up employment at small-car plants without a costly relocation. Fourth, the dealership network and salesforce of the U.S. auto industry had evolved under an era of thriving large-car sales, and they were adapted to market and service larger cars. Fifth, the knowledge base and the research and design personnel at U.S. auto companies were specialized in engineering larger cars. The development of smaller, more fuel-efficient cars required a reorientation of the knowledge base and the development of new skills by research and design personnel. Over time, U.S. automakers adapted to the shift in demand for vehicle types, but much of the creation response involved the entry and expansion of new facilities in the United States built and operated by Japanese automakers (Mair, Florida and Kenny, 1988).

Let's return to the broader reallocative consequences of the COVID-19 shock. Even with a vaccine in hand, consumer spending patterns, business practices and working arrangements won't fully revert to pre-pandemic patterns. Concerns about infectious disease will linger. Millions of households are learning how to purchase almost anything online, and many will stick with it. Business people are learning how to travel less, and employees and firms are learning how make working from home work. Much of the shift in spending patterns and business practices will persist. National borders have been closed to most, often almost all, travel in countries around the world. Even when the pandemic recedes, stricter border controls, health checks and travel restrictions will likely remain in effect for years. However well advised, these policies will curtail international travel for business, tourism, and scientific conferences. In addition, the long expansion that preceded the COVID-19 shock probably delayed the exit and contraction of marginal businesses, factories and product lines that were sliding toward obsolescence in any event. By depressing demand now and for at least several months, the COVID-19 shock triggered a recession that is likely to involve cleansing dynamics, as in the model of Caballero and Hammour (1994).26 These are among the reasons to think that the reallocative effects of the COVID-19 shock will persist long after the pandemic recedes.

${ }_{26}$ Permanent factory closures post-COVID include a dishware maker in North Carolina, a furniture foam maker in Oregon, a plant in Indiana owned by a boat and motor-cycle maker, a tire plant in Alabama, a producer of cutting board and industrial table tops in Michigan, a mattress maker in Michigan, two printing plants in Missouri, and a maker of china dishes in North Carolina (Hufford and Tita, 2020). 


\section{c. Potential for Transformative Shifts}

Jones et al. (2008) document the emergence of 335 new infectious diseases in human populations from 1940 to 2004, with a rising incidence over time even after efforts to control for reporting bias. Urbanization, long-distance travel, and cross-border commuting create the potential for new disease outbreaks to spread rapidly and become global pandemics. If major pandemics become a recurring phenomenon, we may see population shifts away from densely populated cities. Even if those shifts are largely confined to retirees and the well off, it would involve a large reallocation of business, jobs, workers and capital. Persistent concerns about disease transmission will also provide strong impetus for new products and new efforts to allay customer concerns about infection risks. Driverless taxis that automatically disinfect interior spaces after each passenger trip is but one possibility among many.

The capacity for large-scale, necessity-driven experiments to drive major shifts in workplace organization is well captured by Morgan Stanley's CEO James Gorman on a midApril earnings call: "If you'd said three months ago that $90 \%$ of our employees will be working from home and the firm would be functioning fine, I'd say that is a test I'm not prepared to take because the downside of being wrong on that is massive." In addition to Morgan Stanley and Facebook, Twitter, OpenText, Shopify, Snap (a messaging company), Skift (a business media company), and Discovery (parent of TV channels TLC and Food Network) have also indicated they plan large, permanent increases in working from home (Horwitz, 2020, and Mattioli and Putzier, 2020). According to a survey of 500 "hiring decision makers" fielded from 22-28 April 2020, 62 percent of respondents say working from home will increase in their organizations "as a result of their experiences during COVID19." 2756 percent of the respondents say working remotely has exceeded their expectations, as compared to 9 percent that say it has fallen short.

27 See Upwork (2020) and the slide deck at www.slideshare.net/upwork/2020-future-workforce-report/1. The survey covers most major industry sectors. 43 percent of respondents are from companies with more than 1,000 employees. 
Other companies may want to re-locate office space from central cities to suburban locations to reduce the need for long (and crowded) commutes and high-density workplaces. Both the shift to working from home and the relocation of office activity from urban cores to suburban locations will reduce worker spending in the central business districts of major cities.

Shiva (2020) argues that countries around the world need large investments to upgrade public health systems and healthcare capacity: hospitals, treatment capabilities, protective gear for front-line healthcare workers, greatly enhanced testing capabilities, vaccine stocks, and stockpiles of masks and equipment to control and monitor infection risks. In the wake of the COVID-19 pandemic and its enormous economic toll, arguments for greater investments in public health systems and healthcare capacity will have broad appeal. Thus, it seems a good bet that many countries, including the United States, will indeed undertake large-scale investments in public health systems, healthcare capacity, and medical research in the next several years.

\section{Messages for Policy}

\section{a. Many Lost Jobs Are Gone for Good}

Many American jobs lost since early March will return over the ensuing weeks and months as the pandemic recedes and lock downs end. Many other jobs are gone for good. According to Table 3, employers perceived 23.5 percent of their layoffs from March 1 to mid-May as permanent at the time of job loss. A Washington Post/Ipsos survey of 8,086 American adults fielded from 27 April to 4 May 2020 also finds that 23 percent of layoffs were perceived as permanent when they happened.28 Claimants for unemployment benefits in California from March to May 2020 perceived 23.2 percent of their job losses as permanent as of the filing date.29 In Appendix A, we develop two estimates for the permanent-layoff share of job losses between March and April 2020 using the Current Population Survey. Our lower CPS-based estimate of 26 percent arises by treating persons absent from work with pay for "other reasons"

28 See https://context-cdn.washingtonpost.com/notes/prod/default/documents/7a39185f-8222-4e28-95285741ebb137ad/note/2e 5183d3-9f6f-45a1-84ab-7f2532c8c5fb.\#page=1. 29 Muhammad Akhtar and Till von Wachter kindly supplied the California data. See Appendix B. 
as on temporary layoff. Our higher estimate of 34 percent treats these persons as employed. A survey of 500 "hiring decision makers" commissioned by Upwork and fielded from 22-28 April finds that 47 percent of recent layoffs were perceived as permanent. 30

As we discuss in Appendix A, it is challenging to estimate the permanent-layoff share of job losses using CPS data.31 The 47 percent figure from Upwork Survey is an outlier, and we are inclined to discount it.32 We prefer the permanent-layoff figures derived from the SBU, Washington Post/Ipsos poll, and California unemployment claimants. Thus, we use SBU figures in our base-case projections for the fraction of pandemic-induced job losses that ultimately turn out to be permanent in the sense that the job loser does not return to a job at his or her previous employer. Recall that 27.9 million Americans filed new claims for unemployment benefits in the six weeks ending April 25. Multiplying 27.9 million by the 23.5 percent permanent-layoff share in the SBU yields 6.5 million permanent layoffs.

Of course, there remains tremendous uncertainty about the economic outlook. For many firms, today's cash-flow problems will become tomorrow's insolvencies, and "temporary" layoffs will become permanent.33 The longer the recovery takes, the larger the fraction of recent layoffs that will turn out to be permanent. To get a sense for the fraction of layoffs that will lead to actual recalls, we turn to historical evidence from two sources. Using a sample of UI recipients in Missouri and Pennsylvania from 1979 to 1981, Katz and Meyer (1990) find that 72 percent of UI recipients who initially anticipated recall were actually recalled. In addition, 13 percent of ex ante "permanent" layoffs were, in fact, recalled. Giuseppe Moscarini kindly provided us with alternative estimates based on Survey of Income and Program Participation data from 1990 and the analysis in Fujita and Moscarini (2017). He estimates that 87.5 (6.6) percent of layoffs perceived as temporary (permanent) at the time of job loss led to actual recalls.

30 See Upwork (2020) and the slide deck at www.slideshare.net/upwork/2020-future-workforce-report/1. 31 Appendix A also explains why the headline CPS statistic for the share of unemployed persons on temporary layoffs is not a sound estimate for the permanent-layoff share of job losses.

32 Why the Upwork survey yields such a high permanent-layoff share is unclear to us. However, the 47 percent figure appears to reflect an equal-weighted response. If smaller organizations have higher permanent-layoff shares, that would help explain why the Upwork figure is so large.

33 For anecdotal evidence of how "temporary" layoffs are becoming permanent in the wake of COVID19, see Morath (2020). 
Applying the Katz-Meyer figures to statistics in the rightmost column of Table 3 implies actual recalls equal to

$$
(0.72)[11.4 / 14.9]+0.13[(1.5+2.0) / 14.9]=58 \%
$$

percent of gross staffing reductions. This calculation adjusts for "permanent" layoffs that result in recalls and treats cuts in contractors and leased workers like permanent layoffs. According to this calculation, 42 percent of gross staffing reductions in Table 3 will result in permanent layoffs. Applying the 42 percent figure to the 27.9 million new claims for unemployment benefits in the six weeks ending on April 25 yields 11.6 million permanently lost jobs. This number does not include later job losses caused by the COVID-19 shock. Applying instead the recall rates from Moscarini yields 32 percent as the realized permanent-layoff share of COVIDinduced jobs losses. In Appendix B, we report the results of analogous calculations for the other estimates of the share of layoffs perceived as permanent at the time of job loss. We obtain twelve projections for the realized permanent-layoff share. They range from 30 to 48 percent excepting those based on the Upwork survey, which exceed 50 percent. Clearly, there is much uncertainty about the share of pandemic-induced layoffs that will ultimately result in permanent layoffs. This uncertainty should not distract from the key point: Many millions of jobs lost during the pandemic recession will result in permanent layoffs.

Our earlier remarks on the potential for concerns about infectious disease transmission to alter retail formats, restaurant designs, working arrangements, and the delivery of medical, professional, personal and business services suggest that the reallocative consequences of the COVID-19 pandemic will continue to play out for many months and years to come. Broadly speaking, we anticipate permanent job losses in three overlapping categories: jobs lost due to COVID-induced demand shifts, jobs formerly at marginal firms that don't survive the pandemic and lockdown, and jobs lost due to the spatial and intra-industry reallocation triggered by the pandemic and by post-pandemic concerns about the transmission of infectious diseases. Sections I and II above draw on multiple sources of evidence, and a few historical experiences, to explain why we anticipate a sizable number of permanently lost jobs in each category.

If we are correct that many lost jobs are gone for good, there are important implications for policy. First, policy efforts to preserve all pre-COVID jobs and employment relationships could 
prove quite costly. They are analogous to policies that prop up dying industries and failing firms. These policies are feasible, but the cost is high in terms of resource misallocation and taxpayer burden. Second, there are large benefits of policies and policy reforms that facilitate a speedy reallocation of jobs, workers, and capital to newly productive uses in the wake of the pandemic. Policies that deter or slow factor reallocation are likely to further lengthen the lag of creation behind destruction, slowing the overall recovery from the pandemic, the lockdown, and the pandemic-induced reallocation shock.

In the rest of the paper, we develop these themes in connection with specific policy interventions and legacy features of the U.S. policy landscape. We focus on policies that directly impact the economy's reallocation response to the COVID-19 shock. Policies that facilitate productive reallocation can also ease supply constraints and complement the role of fiscal and monetary policy in stabilizing demand. In turn, aggregate demand stabilization and monetary policy actions that ensure the smooth functioning of the financial system help set the stage for a speedier reallocation of jobs, workers, and capital to their most efficient uses.

\section{b. High Unemployment Benefits Encourage Layoffs, Discourage Work, and Delay Productive Reallocation}

President Trump signed the Coronavirus Aid, Relief, and Economic Security (CARES) Act on 27 March 2020. As part of this relief bill, the federal government is supplementing unemployment insurance (UI) benefit levels by $\$ 600$ per week through the end of July 2020.34 Each UI recipient receives the extra $\$ 600$ per week irrespective of previous earnings or their potential earnings on a new job.35 For many workers, the extra $\$ 600$ pushes total unemployment benefits to levels that exceed their previous earnings.

34 The Federal Pandemic Unemployment Compensation provision of the CARES Act also expanded UI eligibility to independent contractors, gig workers, self-employed persons and to certain persons who are "unable or unavailable to work because of certain health or economic consequences of the COVID-19 pandemic," extended the duration of unemployment benefits by up to 13 weeks, and relaxed job search requirements. See the U.S. Department of Labor at https://www.dol.gov/coronavirus/unemploymentinsurance, accessed on 28 April 2020.

${ }_{35}$ See the Department of Workforce Development at https://dwd.wisconsin.gov/uiben/fpuc/ for a description of how the State of Wisconsin is implementing the supplemental UI benefits 
According to an analysis of this provision in Williams (2020), "the average replacement rate across states would increase to roughly 116 percent.... The expanded benefits exceed 90 percent of the average weekly wages in all states; they exceed 120 percent of average wages in 21 states and 130 percent in six states." Similarly, the Council of Economic Advisers estimates that 64 percent of workers would receive more income from unemployment benefits than from working until the end of July when the $\$ 600$ federal supplement expires. Industries like hospitality and retail have an even greater share of workers for whom unemployment benefits exceed earnings.36 Ganong, Noel and Vavra (2020) estimate that, under the CARES Act, the median replacement rate for unemployment benefit recipients is 134 percent. They also estimate that two-thirds of eligible workers receive benefits that exceed lost earnings, and the one-fifth receive benefits that are at least twice as high as lost earnings.

The newly generous unemployment benefit levels are not lost on employers. "When Equinox had to start furloughing some employees at its chain of upscale fitness clubs, Executive Chairman Harvey Spevak had a surprising message to stakeholders. 'We believe most will be better off receiving government assistance during our closure'." This passage is from Thomas and Cutter (2020), who also write: “Equinox joins a number of companies, including Macy's ... and [furniture maker] Steelcase ...that are citing the federal government's beefed-up unemployment benefits as they furlough or lay off staff amid the coronavirus pandemic. The stimulus package is changing the calculus for some employers, which can now cut payroll costs without feeling they are abandoning their employees." Thomas and Cutter also report that some workers in "essential businesses," who would receive more income while unemployed are asking to be laid off. These remarks suggest that federal supplemental unemployment benefits have boosted layoffs and unemployment benefit claims during the pandemic.

The extra $\$ 600$ per week in supplemental benefits is also likely to discourage many unemployed persons from returning to work before August. Even at replacement rates in the historical range of 40-50 percent of prior earnings, unemployment benefits discourage job search by recipients. See, for example, the studies by Katz and Meyer (1990) and Krueger and Mueller 
(2010). Evidence has already emerged that today's much higher replacement rates are discouraging a return to work. Huffman (2020) and Kullgren (2020), for example, offer anecdotal evidence from the restaurant industry. The problem will worsen as the economy reopens and employers seek to recall laid-off employees or hire new ones. On 15 May 2020, the House passed the Heroes Act, which would extend the supplemental \$600 per week through January 2021 (with a phaseout through March 2021) and disregard the value of supplemental benefits in assessing eligibility for other means-tested federal assistance programs (Weidinger, 2020). If enacted, these provisions in the Heroes Act would further discourage a return to work and slow the economy's response to the reallocative aspects of the COVID-19 shock.

Prang (2020) supplies an interesting example of how the $\$ 600$ supplemental benefit is affecting a cleaning company that employed 30 workers before the pandemic. The owner received a \$250,000 loan under the Paycheck Protection Program. Under the terms of the program, the loan is forgivable if the company reopens within eight weeks and rehires its former employees. The owner thinks it will take longer than eight weeks to reopen, and that it is "unclear if his workers would want to stay at the firm over the next couple of months because many of them stand to make more from the country's expanded unemployment benefits. Mr. Walsh [the owner] estimated he would have to raise the pay of certain employees by up to $40 \%$ to compete with collecting unemployment." Many owners and managers will confront similar challenges as they seek to reopen their businesses in the near future.

\section{c. Linking Firm Aid to Employee Retention Deters Productive Reallocation}

The CARES Act also created the Paycheck Protection Program (PPP), an emergency lending facility that extends loans to small businesses on favorable terms. Congress allocated $\$ 349$ billion to the PPP in the CARES Act and added another \$321 million about a month later, bringing the total to $\$ 670$ billon (Boggs, 2020). As Letteiri and Lyons (2020) explain, the PPP has two main goals: "1) help small businesses cover their near-term operating expenses during the worst of the crisis, and 2) provide a strong incentive for employers to retain their employees." Loans are forgivable in an amount up to the borrower's expenditures on payroll, rent, utilities, and mortgage interest in the eight weeks after loan receipt, if the borrower maintains their precrisis level of full-time equivalent employees. Otherwise, the amount forgiven falls in proportion 
to the headcount reduction. (Payroll expenses must account for at least 75 percent of the forgiven amount.) Thus, the loan becomes a grant if covered operating costs exceed the loan amount and the borrower maintains headcount.

The efficiency rationale for the PPP is straightforward, though seldom articulated: If there is social value to business continuity that exceeds the private value captured by owners, employees, suppliers and customers, then taxpayer subsidies that encourage the operation of temporarily unprofitable businesses might create positive social value. We say "might" here, because these subsidies involve other costs, including the deadweight cost of taxation.

We make no effort to analyze the full range of benefits and costs of the PPP or to assess its implementation. Our more modest aim is to highlight the program's effects on reallocation incentives and static efficiency in the wake of the COVID-19 shock. Given the program's design, an eligible firm has strong financial incentives to tap the PPP to fund eight weeks of current operations, even when its output during that period has negative social value, and its workers and other inputs would be more efficiently deployed elsewhere.37

Consider, for example, a restaurant that can generate revenues of $\$ 5,000$ a week during the crisis at a cost of $\$ 8,000$ per week for payroll and $\$ 2,000$ for food and utilities. The short-run profit maximizing decision for the restaurant owner is to shut down during the crisis, saving $\$ 5,000$ a week. That privately sensible decision also frees up the employees to take another job or collect unemployment benefits and, if not working, to devote more time to valuable activities at home such as caring for children and monitoring their studies while schools are closed.38 That same owner with a PPP loan of $\$ 64,000$ will find it profitable to stay open. The forgivable loan covers labor costs during the eight-week period, leaving net profits of $\$ 3,000$ per week for the

${ }_{37}$ Our discussion in the main text pertains to the PPP as originally created in the CARES Act. On 3 June 2020, Congress passed the Paycheck Protection Flexibility Act, which instituted major reforms to the PPP. Among other things, the reforms greatly relax employee retention requirements, extend the period over which borrowers can accrue operating expenses for loan forgiveness, and lower the amount firms must spend on payroll to qualify for loan forgiveness. See Lyons (2020) for a useful summary. These reforms mitigate the efficiency concerns with the original PPP, and we see them as a belated, partial recognition of problems inherent in the design of the PPP. 38 Some laid-off workers may not qualify for unemployment benefits, even under the relaxed criteria provided by the CARES Act. If that is the concern, lawmakers can further relax the eligibility criteria for unemployment benefits. 
restaurant owner. In this example, the taxpayer foots the bill to subsidize business operations that have negative social value. Through the forgivable loan, the PPP incentivizes the owner to employ workers whose time has higher value in other jobs and non-market activities.

The PPP also creates incentives to delay socially valuable reallocation responses to the COVID-19 shock. To see this point, return to the example and suppose the owner anticipates the restaurant will remain unprofitable even after the pandemic recedes and the lockdown ends. This scenario is a likely one for many restaurants, because the fall in demand for dine-in restaurants will persist, as we discussed above. As of mid-June 2020, the number of seated diners is 70-75 percent lower than a year earlier, according to data for restaurants in the OpenTable network.39 Even in these circumstances, the PPP gives the restaurant owner a financial incentive to continue operating for as long as forgivable loans are available to turn an unprofitable business into a privately profitable one. In other words, the PPP creates financial incentives to keep workers engaged in businesses that cannot succeed beyond the duration of government subsidies, and to postpone their redeployment to viable businesses.

There are more efficient ways to channel liquidity support to viable, cash-strapped businesses during the crisis. Delinking financial assistance to firms from employee retention would largely eliminate the incentive to inefficiently deploy labor. Assistance in the form of lowinterest loans without forgiveness provisions would discourage firms with poor economic outlooks from applying for assistance. That way, taxpayer-backed programs to provide liquidity support for businesses could be allocated to firms with reasonable survival prospects. Modifying the PPP in these two respects would also facilitate a speedier reallocation of factor inputs away from businesses with poor future prospects in the wake of the COVID-19 shock to existing and new businesses with better prospects.

In Sections I and II, we presented evidence that the COVID-19 shock caused large, persistent shifts in demand patterns, working arrangements, and business practices. The reallocative aspects of the shock imply that many businesses should not return to pre-COVID

39 The data, summarized at www.opentable.com/state-of-industry, cover seated diners (online, phone and walk-in reservations) in a sample of 20,000 restaurants in North America, Germany, Ireland and the United Kingdom that are members of the OpenTable network. 
employment levels, and they will not do so without employment-retention subsidies of indefinite duration. This point applies well beyond the PPP to other programs that use taxpayer funds to underwrite employee retention regardless of the employer's commercial outlook. For example, the U.S. Treasury struck an agreement with ten major U.S. airlines to provide $\$ 25$ billion in subsidies in exchange for barring layoffs and furloughs before October (Sider, 2020a). But airline executives say "it will likely take years to get back to travelling as usual" (Sider, 2020b). According to Transportation Security Administration data, passenger counts at U.S. airports are, relative to a year earlier, down 93 percent on 31 March 2020, 94 percent on 30 April and 87 percent on 30 June.40 As of mid-June, American Airlines plans to restart 55 percent of its domestic flights in July while keeping international flights at 20 percent of pre-pandemic levels (Katz, 2020). Capacity will rise much less, because airlines are blocking many seats to maintain social distancing and allay passenger concerns about disease transmission (McCartney, 2020). Both American Airlines and United Airlines announced in May plans to cut management and administrative ranks by 30 percent (Sider, 2020c). Boeing plans to cut 13,000 jobs in the U.S. in view of the collapse in air travel, and its suppliers have announced additional job cuts (Cameron, 2020). In circumstances like these, employee-retention subsidies delay the redeployment of workers and other productive inputs to more efficient uses during the crisis and afterwards.

\section{d. Land-Use Restrictions}

Certain legacy features of the U.S. policy landscape will also, unless reformed, inhibit the economy's response to the reallocative nature of the COVID-19 shock. To take one example, more stringent land-use regulations and greater organized political opposition to new real estate developments have reduced the elasticity of housing supply in many U.S. cities since the 1960s (Glaeser and Gyourko, 2018). These regulations take the form of minimum lot sizes, density restrictions, building height restrictions, urban growth boundaries, environmental impact rules designed to slow or stop development, and other land-use restrictions. 41

40 See TSA's “Total Traveler Throughput” data at www.tsa.gov/coronavirus/passenger-throughput. ${ }_{41}$ Gyourko and Molloy (2015) review evidence that land-use restrictions raise housing prices and reduce the elasticity of housing supply. Their Figure 1 shows that real house prices rose by 60 percent relative to real construction costs from the early 1980s to 2014. Glaeser, Gyourko and Saks (2005) present evidence that land-use restrictions play an especially important role in driving housing prices above construction 
By making it costlier for businesses and workers to move to the most productive cities, Hsieh and Moretti (2019) conclude that housing supply restrictions lowered aggregate U.S. growth by 36 percent from 1964 to 2009. Duranton and Puga (2019) also find large negative effects of residential land-use restrictions on aggregate growth in a model that explicitly considers the tradeoff between agglomeration benefits and congestions costs. Their model endogenizes excessive land-use restrictions as the outcome of decentralized political decisionmaking. In the political-economic equilibrium, land-use restrictions optimize the tradeoff between benefits and costs of population growth for local incumbents, while ignoring the impact on (potential) newcomers and creating deadweight losses for society.

Herkenhoff, Ohanian and Prescott (2018) consider state-level policies that restrict land availability for both housing and commercial purposes. Using a state-level growth model, they simulate the effect of moving all U.S. states halfway from their current land-use regulations to that of Texas, the least-restrictive state. Their model implies that such a move would lead to substantial population reallocations across U.S. states and raise aggregate U.S. output by 12 percent. In an empirical study, Ganong and Shoag (2017) link the slowing of cross-state income convergence since the 1980 s to rising housing supply regulations.

\section{e. Occupational Licensing Restrictions}

Government-mandated restrictions on who can work in what jobs are another important class of policies that impede responses to reallocative shocks. The share of American workers who must hold a license to do their jobs rose from less than $5 \%$ in the 1950 s to more than $25 \%$ by 2008 (Kleiner and Krueger, 2013). About one-third of the growth in occupational licensing since the 1960s reflects changes in the mix of jobs.42 The other two-thirds reflects a greater prevalence of licensing requirements within occupations. Carpenter et al. (2012) provide an illuminating description of state licensure requirements in 102 low- and moderate-income occupations. They document onerous licensing requirements for barbers, manicurists, tree trimmers, funeral attendants, massage therapists, auctioneers, sign language interpreters, and

costs in several major coastal cities - including New York, Boston, Los Angeles, San Jose, and San Francisco.

42 U.S. Department of the Treasury Office of Economic Policy (2015), page 20. 
hundreds of other jobs.43 According to the Council of State Governments, "over 1,100 jobs were licensed, certified, or registered in at least one state." (U.S. Department of Treasury Office of Economic Policy, 2015, page 7)

Most occupational licenses are at the state level and cross-state reciprocity is limited. Thus, licensing raises entry barriers in many jobs and inhibits worker mobility across states. See Carpenter et al. (2012), the U.S. Treasury Office of Economic Policy (2015), Johnson and Kleiner (2017), Kleiner and Xu (2019) and Hermansen (2019) for evidence that licensing reduces job-to-job mobility among workers, lowers occupational entry rates, reduces interstate mobility rates of workers in affected occupations, and lowers inward worker migration in states with more extensive and stricter licensing regulations. For a fuller set of references to studies of occupational licensing effects, see Farronato et al. (2020).

Occupational licensing restrictions have recently presented themselves in a particularly pointed manner, as observed in a recent Wall Street Journal (2020) editorial:

Last month [New York Governor] Cuomo allowed medical personnel licensed anywhere in the country to practice in the state without a New York license. The Governor also expanded "scope-of-practice" rules to allow nurse practitioners, physician assistants and nurse anesthetists to perform jobs they've been trained to do without supervision from a higher-trained professional... Washington, Colorado and Massachusetts are relaxing licensing for out-of-state medical professionals. Florida Gov. Ron DeSantis last month signed legislation allowing primary-care nurse practitioners and advanced-practice registered nurses to operate independently. Another new law would let pharmacists test and treat common ailments like the flu and strep throat.

Relaxing restrictions of this sort are thus one route to facilitating a helpful response to the pandemic and the necessary post-pandemic reallocation of resources. The U.S. Department of the Treasury Office of Economic Policy (2015) and Thierer (2020) provide several proposals for reforming occupational licensing practices in the United States.

${ }_{43}$ These examples are drawn from Table 1 in Carpenter et al. (2012). 


\section{f. Regulatory barriers to business formation and expansion}

As we have stressed, the COVID-19 pandemic precipitated a major reallocation shock to the U.S. economy. The strength of the recovery will turn partly on how successfully the economy responds to the reallocative aspects of the shock. In this regard, there are reasons for concern beyond the ones identified above. Available evidence suggests the U.S. economy responds more sluggishly to reallocation shocks now than decades earlier, and that regulatory barriers to business entry and expansion are important reasons for the increased sluggishness.

Decker et al. (2018) present evidence that plant-level employment growth became less responsive to plant-level total factor productivity (TFP) shocks after the 1980s in the U.S. manufacturing sector. Among plants operated by young firms in high-tech manufacturing, the fall in responsiveness began after the 1990s. Plant-level investment rates also became less responsive to TFP shocks after the 1990s. Moreover, the intra-industry dispersion of labor productivity has drifted upwards since at least the mid-1990s. Decker et al. also find that firmlevel employment growth became less sensitive to labor productivity shocks in the U.S. nonfarm private sector since the mid-1990s, and that the intra-industry dispersion of labor productivity has risen since the mid-1990s. All of these findings point to greater sluggishness in responding to firm-level and establishment-level shocks.

Gutierrez and Philippon (2019) find that the elasticity of market entry with respect to Tobin's $q$ has declined since the late 1990s. They attribute this development mainly to rising entry costs driven by regulations and lobbying. Their evidence points to greater sluggishness at the level of markets in the U.S. economy. It is complementary to the plant-level and firm-level evidence in Decker et al. (2018).

Davis (2017) presents evidence that the U.S. regulatory and tax systems grew enormously in scale, scope and complexity in recent decades. He argues that regulatory burdens and complexity tend to fall more heavily on younger firms and incumbent businesses that expand into new markets. A vast, complex regulatory landscape creates large costs of learning the relevant regulations, developing compliance systems, and establishing relationships with regulators. Young businesses have had less time to develop the knowledge and internal processes required for compliance. Partly for this reason, complex regulatory systems favor incumbents 
while disadvantaging entrepreneurship and young businesses. Compared to smaller, newer and would-be competitors, larger and incumbent firms have greater capacity and incentive to lobby for legislative exemptions, administrative waivers, and favorable regulatory treatment. Similar remarks apply to the U.S. business tax code, which is also vast and complex.

We conclude with remarks on one class of regulations that is especially pertinent in light of the COVID-19 shock: Certificate of Need (CON) laws in the healthcare sector. As described by Mitchell (2020), these laws "limit the ability of healthcare professionals to open new facilities, expand existing ones, or offer new services.... [They] cover dozens of technologies and services ... and are not intended to evaluate a provider's competency or safety record. Instead, [the CON process] is intended to evaluate the provider's claim that the service is actually needed.... Incumbent providers are invited to challenge the applications of their wouldbe competitors. Even if a CON is granted, applicants can expect the process to take months or years." In light of this description, the potential for CON laws to deter entry, reduce healthcare capacity, and inhibit the healthcare sector's responsiveness to reallocation shocks is obvious.

The number of U.S. states with CON laws went from zero before 1964 to 23 in 1970 and 49 in 1980 (Mitchell and Koopman, 2016). Since then, many states have repealed CON laws, and they are currently in effect in 35 states and the District of Columbia. The adoption and repeal of CON laws at different times in different states is quite useful for research into their effects. According to Mitchell's (2020) timely summary of research in this area, CON laws are associated with fewer hospitals per capita, fewer hospital beds per capita, fewer ambulatory surgery centers per capita, fewer hospice care facilities, fewer dialysis clinics, fewer hospitals offering MRI, CT and PET scans, and longer driving distances to obtain care.

This evidence supports two conclusions: First, that CON laws contributed to hospital capacity shortfalls during the COVID-19 pandemic. Second, that CON laws will hamper the healthcare sector's response to demand shifts driven by the COVID-19 shock and make it harder and costlier to strengthen healthcare capacity in the United States. Mitchell, Amez-Droz and Parsons (2020) offer several suggestions for phasing-out or otherwise reforming CON laws. 


\section{References}

Alfonso, Gara and Ricardo Lagos, 2015. "Trade Dynamics in the Market for Federal Funds," Econometrica, 83, no. 1, 263-313.

Altig, Dave, Scott Baker, Jose Maria Barrero, Nick Bloom, Phil Bunn, Scarlet Chen, Steven J. Davis, Julia Leather, Brent Meyer, Emil Mihaylov, Paul Mizen, Nick Parker, Thomas Renault, Pawel Smietanka and Greg Thwaites, 2020. "Economic Uncertainty Before and During the COVID-19 Pandemic,” NBER Working Paper 27418, June.

Altig, David, Jose Maria Barrero, Nick Bloom, Steven J. Davis, Brent Meyer, Emil Mihaylov and Nick Parker, 2020a. "American Firms Foresee a Huge Negative Impact of the Coronavirus," Technical Report, Federal Reserve Bank of Atlanta, 23 March.

Altig, David, Jose Maria Barrero, Nick Bloom, Steven J. Davis, Brent Meyer, Emil Mihaylov and Nick Parker, 2020b. "COVID-19 Caused 3 New Hires for Every 10 Layoffs," Technical Report, Federal Reserve Bank of Atlanta, 1 May.

Altig, David, Jose Maria Barrero, Nick Bloom, Steven J. Davis, Brent Meyer and Nick Parker, 2020c. "Surveying Business Uncertainty" NBER Working Paper 25956. Revised, March 2020. Forthcoming, Journal of Econometrics.

Bachmann, Ruediger, Kai Carstensen, Stefan Lautenbacher and Martin Schneider, 2018. "Uncertainty and Change: Survey Evidence of Firms' Subjective Beliefs," working paper.

Bachmann, Ruediger and Stefan Elstner, 2015. "Firm optimism and pessimism," European Economic Review, 79 (October), 297-325.

Baker, Scott, Nicholas Bloom, Steven J. Davis, Kyle Kost, Marco Sammon and Tasaneeya Viratyosin, 2020. "The Unprecedented Stock Market Reaction to COVID-19," COVID Economics: Vetted and Real-Time Papers, 1, 5 April. Revised and expanded on 16 June.

Baker, Scott, Nicholas Bloom, Steven J. Davis and Stephen J. Terry, 2020. "COVID-Induced Economic Uncertainty," NBER Working Paper 26983.

Baldwin, Richard and Beatrice Weder di Mauro, 2020. "Introduction," in Baldwin and Weder di Mauro, editors, Economics in the Time of COVID-19, CEPR, London, pp. 1-30.

Bandolm, Lana, 2020. "Papa John's Plans to Hire 20,000 Workers During Coronavirus Outbreak," Forbes, 23 March.

Bansal, Ravi, Marian Max Croce, Wenxi Liao, and Samuel Rosen, 2019. "Uncertainty-Induced Reallocations and Growth," NBER Working Paper No. 26248.

Bartik, Alexander W., Maranne Bertrand, Zoe B. Cullen, Edward L. Glaeser, Micahel Luca, and Christopher T. Stanton, 2020. "How Are Small Businesses Adjusting to COVID-19? Early Evidence from a Survey,” NBER Working Paper No. 26989.

Bender, Ruth and Matthew Dalton, 2020. "Coronavirus Pandemic Compels Historic Labor Shift: Outbreak Reshapes Job Market as Some Sectors Shut Down, Other See Demand Surge," Wall Street Journal, 29 March 2020.

Barrero, Jose Maria, 2020. “The Micro and Macro of Managerial Beliefs," working paper, Instituto Tecnológico Autónomo de México. 
Bloom, Nicholas, Philip Bunn, Scarlet Chen, Paul Mizen, Pawel Smietanka, Greg Thwaites and Garry Young, 2018. "Brexit and uncertainty: insights from the Decision Maker Panel," Fiscal Studies, 39, no. 4, 555-580.

Bloom, Nicholas, Steven J. Davis, Lucia Foster, Brian Lucking, Scott Ohlmacher and Itay Saporta Ecksten, 2017. "Business-Level Expectations and Uncertainty," working paper.

Boggs, Justin, 2020. "Congress Approves Replenishing the Paycheck Protection Program," Denver Channel, 23 April.

Brainard, S. Lael and David M. Cutler, 1993. "Sectoral Shifts and Cyclical Unemployment Reconsidered," Quarterly Journal of Economics, 108, no. 1 (February): 219-243.

Bresnahan, Timothy F. and Valery A. Ramey, 1993. "Segment Shifts and Capacity Utilization in the U.S. Automobile Industry," American Economic Review, 83, 2, 213-218.

Broda, Christian and David E. Weinstein, 2010. "Product Creation and Destruction: Evidence and Price Implications," American Economic Review, 100 (June), 691-723.

Brynjolfsson, Eric, John J. Horton, Adam Ozimek, Daniel Rock, Garima Sharma and Hong-Yi TuYe, 2020. "COVID-19 and Remote Work: An Early Look at U.S. Data," NBER Working Paper 27344.

Bureau of Labor Statistics, U.S. Department of Labor, 2017. "Contingent and Alternative Employment Arrangements - May 2017," at www.bls.gov/news.release/pdf/conemp.pdf.

Caballero, Ricardo and Mohammed Hammour, 1994. "The Cleansing Effect of Recessions," American Economic Review, 84, no. 5 (December), 1350-1368.

Cajner, Tomaz, Leland D. Crane, Ryan A. Decker, John Grigsby, Adrian Hamins-Puertolas, Erik Hurst, Christopher Kurz and Aju Yildirmaz, 2020. "The U.S. Labor Market during the Beginning of the Pandemic Recession," June. Prepared for the Brookings Papers on Economic Activity.

Cameron, Doug, 2020. “Boeing Details Plans for Mass Job Cuts," Wall Street Journal, 27 May.

Campbell, John Y. and Robert J. Shiller, 1988. "The Dividend-Price Ratio and Expectations of Future Dividends and Discount Factors," Review of Financial Studies, 1, 195-228.

Carew, Sinead, 2020. “Goldman Sachs Slashes U.S. GDP Estimate Further," U.S. News \& World Report, 31 March.

Carpenter, Dick M., Lisa Knepper, Angela C. Erickson, and John K. Ross. 2012. License to Work: A National Study of Burdens from Occupational Licensing, Arlington, VA: Institute for Social Justice.

Chen, Cheng, Tatsuro Senga, Chang Sun and Hongyong Zhang, 2019. "Uncertainty, Imperfect Information and Learning in the International Market," working paper.

Cochrane, John, 2011. "Presidential Address: Discount Rates," Journal of Finance, 68, no. 4, 1047-1108.

Craig, Ben R. and Joseph G. Haubrich, 2013. "Gross Loan Flows," Journal of Money, Credit \& Banking, 45, no. 2-3.

Cutter, Chip and Patrick Thomas, 2020. "Looking for a Job? Big Tech Is Still Hiring?" Wall Street Journal, 14 April. 
Davis, Steven J., 1987. "Fluctuations in the Pace of Labor Reallocation," Carnegie-Rochester Conference Series on Public Policy, 27, 335-402.

Davis, Steven J., 2017. "Regulatory Complexity and Policy Uncertainty: Headwinds or Our Own Making," Becker Friedman Institute Working Paper, April.

Davis, Steven J., Jason Faberman, and John Haltiwanger, 2006. "The Flow Approach to Labor Markets: New Data Sources and Micro-Macro Links," Journal of Economic Perspectives, 20, no. 3 (Summer), 3-26.

Davis, Steven J., Jason Faberman, John Haltiwanger and Ian Rucker, 2010. “Adjusted Estimates of Worker Flows and Job Openings in JOLTS," in Labor in the New Economy, edited by K. Abraham, J. Spletzer and M. Harper, University of Chicago Press.

Davis, Steven J. and John Haltiwanger, 1992. "Gross Job Creation, Gross Job Destruction, and Employment Reallocation.” Quarterly Journal of Economics, August.

Davis, Steven J. and John Haltiwanger, 1999. "Gross Job Flows," Handbook of Labor Economics, Volume 3B, Orley Ashenfelter and David Card, editors, Amsterdam: NorthHolland.

Davis, Steven J. and John Haltiwanger, 2001. "Sectoral Job Creation and Destruction Responses to Oil Price Changes," Journal of Monetary Economics, December.

Davis, Steven J., John C. Haltiwanger, and Scott Schuh, 1996. Job Creation and Destruction. Cambridge, MA: MIT Press.

Davis, Steven J., John Haltiwanger, Ron Jarmin, C.J. Krizan, Javier Miranda, Alfred Nucci, and Kristin Sandusky 2009, "Measuring the Dynamics of Young and Small Businesses: Integrating the Employer and Nonemployer Universes". In Producer Dynamics: New Evidence from Micro Data, edited by Timothy Dunne, J. Bradford Jensen and Mark J. Roberts, University of Chicago Press.

Davis, Steven J., Stephen Hansen and Cristhian Seminario, 2020. "Firm-Level Risk Exposures and Stock Price Reactions to COVID-19," working paper.

Davis, Steven J., Prakash Loungani and Ramamohan Mahidhara, 1997. "Regional Labor Fluctuations: Oil Shocks, Military Spending, and other Driving Forces," Board of Governors of the Federal Reserve System, International Finance Discussion Papers 578.

Decker, Ryan A., John C. Haltiwanger, Ron S. Jarmin and Javier Miranda, 2018. "Changing Business Dynamism and Productivity: Shocks vs. Responsiveness,” NBER Working Paper No. 24236.

Dell'Ariccia, Giovanni and Pietro Garibaldi, 2005. "Gross Credit Flows," Review of Economic Studies, 72, 665-685.

Di Mauro, Filipo and Chad Syverson, 2020. "The COVID Crisis and Productivity Growth," VOX CEPR Policy Portal, 16 April 2020.

Dingel, Jonathan I. and Brent Neiman, 2020. "How Many Jobs Can Be Done at Home?" COVID Economics: Vetted and Real-Time Papers, 1, 5 April.

Dunne, Timothy, Mark Roberts, and Larry Samuelson, 1989. "Plant Turnover and Gross Employment Flows in the U. S. Manufacturing Sector," Journal of Labor Economics, 7, 48-71. 
Eisfeldt, Andrea and Adriano A. Rampini, 2006. "Capital Reallocation and Liquidity,” Journal of Monetary Economics, 53, 369-399.

Farronato, Chiara, Andrey Fradkin, Bradley J. Larsen and Erik Brynjolfsson, 2020. "Consumer Protection in an Online World: An Analysis of Occupational Licensing," working paper, March.

Financial Times, 2020. "Prospering in the Pandemic: The Top 100 Companies," 18 June.

Foster, Lucia, John Haltiwanger and C.J. Krizan, 2006. "Market Selection, Reallocation, and Restructuring in the U.S. Retail Sector in the 1990s," Review of Economics \& Statistics, $88,748-758$.

Fujita, Shigeru and Giuseppe Moscarini, 2017. "Recalls and Unemployment," American Economic Review, 107, no. 12 (December), 3875-3916.

Ganong, Peter, Pascal Noel and Joseph Vavra, 2020. "Unemployment Insurance Replacement Rates During the Pandemic," working paper, May.

Ganong, Peter and Daniel Shoag, 2017. "Why Has Regional Income Convergence in the U.S. Declined?" Journal of Urban Economics, 102 (November), 76-90.

Glaeser, Edward and Joseph Gyourko, 2018. "The Economic Implications of Housing Supply, “ Journal of Economc Perspectives, 32, no. 1 (Winter), 3-30.

Glaeser, Edward, Joseph Gyourko and Raven Saks, 2005. "Why Is Manhattan So Expensive? Regulation and the Rise in Housing Prices," Journal of Law and Economics, 48, no. 2 (October), 331-369.

Gormsen, Niels J. and Ralph S. Koijen, 2020. "Coronavirus: Impact on Stock Prices and Growht Expectations," working paper, 23 April.

Green, Jeff and Steve Matthews, 2020. "Reopening U.S. Economy Will Mean Creating All Kinds of New Jobs," Bloomberg Quint, 20 May.

Guerrieri, Veronica, Guido Lorenzoni, Ludwig Straub and Ivan Werning, 2020. "Macroeconomic Implications of COVID-19: Can Negative Supply Shocks Cause Demand Shortages?" NBER Working Paper No. 26918.

Guiso, Luigi and Giuseppe Parigi, 1999. "Investment and demand uncertainty," Quarterly Journal of Economics, 114, no. 1, 185-227.

Gyourko, Joseph and Raven Molloy, 2015. "Regulations and Housing Supply," Handbook of Urban and Economics, Volume 5B, 1290-1337.

Hassan, Tarek A., Stephan Hollander, Laurence van Lent and Ahmed Tahoun, 2020. "FirmLevel Exposure to Epidemic Diseases: COVID-19, SARS, and H1N1," NBER Working Paper No. 26971.

Herkenhoff, Kyle F., Lee E. Ohanian, and Edward C. Prescott, 2018. "Tarnishing the Golden and Empire States: Land-Use Restrictions and the U.S. Economic Slowdown," Journal of Monetary Economics, 93 (January), 89-109.

Hermansen, Mikkel, 2019. "Occupational Licensing and Job Mobility in the United States," OECD Economics Department Working Paper No. 1585.

Herrera, Anna Maria, Marek Kolar and Raoul Minetti, 2011. "Credit Reallocation," Journal of Monetary Economics, 58, 551-563. 
Herrera, Sebastian, 2020. "Amazon to Keep Most of the Jobs It Added During Pandemic," Wall Street Journal, 28 May.

Horn, Daniel, 2020. "The Pandemic Could Put Your Doctor out of Business," Washington Post, 24 April.

Horwitz, Jeff, 2020. "Facebook to Shift Permanently toward More Remote Work after Coronavirus," Wall Street Journal, 21 May 2020.

Huffman, Kurt, 2020. “Our Restaurants Can’t Reopen Till August,” Wall Street Journal, 21 August.

Hufford, Austen and Bob Tita, 2020. "Factories Close for Good as Coronavirus Cuts Demand," Wall Street Journal, 10 May.

Hsieh, Chang-Tai and Enrico Moretti, 2019. "Housing Constraints and Spatial Misallocation," American Economc Journal: Macroeconomics, 11, no. 2, 1-39.

Iacovone, Leonardo and Beata S. Jovorcik, 2010. "Multi-Product Exporters: Product Churning, Uncertainty and Export Discoveries," Economic Journal, 120, Issue 544 (May), 481-499.

International Monetary Fund, 2020. "Chapter 1: The Great Lockdown,” World Economic Outlook, April.

Jackson, Nancy Mann, 2020. "Coronavirus Offers Opportunity for Physicians to Try Telemedicine," Medical Economics, 18 March.

Johnson, Janna E., and Morris M. Kleiner. 2017. "Is Occupational Licensing a Barrier to Interstate Migration?” NBER Working Paper 24107.

Jones, Karen E., Nikkita G. Patel, Marc A. Levy, Adam Storeygard, Deborah Balk, John L. Gittelman and Peter Daszak, 2008. "Global Trends in Emerging Infectious Diseases," Nature, 451, 990-993.

Kapner, Suzanne, 2020a. "J.C. Penny to Close Nearly 30\% of Its Stores," Wall Street Journal, 18 May.

Kapner, Suzanne, 2020b. “Coronavirus Widens the Retail Divide," Wall Street Journal, 21 May.

Katz, Benjamin, 2020. "Inside the Aviation Industry's Toughest Battle Yet: Getting Back in the Skies," Wall Street Journal, 20 June.

Katz, Lawrence F. and Bruce D. Meyer, 1990. "The Impact of the Potential Duration of Unemployment Benefits on the Duration of Unemployment," Journal of Public Economics, 41, no. 1, 45-72.

Kleiner, Morris M., and Alan B. Krueger. 2013. "Analyzing the Extent and Influence of Occupational Licensing on the Labor Market." Journal of Labor Economics 31, no. 2: S173-S202.

Kleiner, Morris M. and Ming Xu, 2020. "Occupational Licensing and Labor Market Fluidity," working paper, August.

Krueger, Alan B. and Andreas Mueller, 2010. "Job Search and Unemployment Insurance: New Evidence from Time Use Data," Journal of Public Economics, 94, nos. 3-4, 546-572.

Kullgren, Ian, 2020. "Restaurants' Bailout Problem: Unemployment Pays More," Politico, 20 April 2020. 
Kuper, Simon, 2020. “The Pandemic Will Forever Change How We Live,” Financial Times, 8 April 2020.

Leatherby, Lauren and David Gelles, 2020. "How the Virus Transformed the Way Americans Spend Their Money," New York Times, 11 April.

Lazear, Edward P. and James R. Spletzer, 2012. "Hiring, Churn, and the Business Cycle," American Economic Review, 102, no. 3, 575-579.

Lee, Dave, 2020a. "Uber Starts Listing Other Jobs for its Drivers," Financial Times, 6 April.

Lee, Dave, 2020b. "US Online Grocery Shopping Jumps as Chains Rush to Add Capacity," Financial Times, 1 June 2020.

Letteiri, John, 2020. "The Paycheck Protection Program Needs Fundamental Improvements, Not Just More Funding," Economic Innovation Group, 16 April.

Letteiri, John and Catherine Lyons, 2020. "Understanding the Paycheck Protection Program," Briefs and Blogs, Economic Innovation Group, 26 March.

Lyons, Catherine, 2020. “Congress Improves the Paycheck Protection Program," 4 June.

Loungani, Prakash, Mark Rush and William Tave, 1990. "Stock Market Dispersion and Unemployment," Journal of Monetary Economics, 25, no. 3 (June), 367-388.

Mair, Andrew, Richard Florida and Martin Kenney, 1988. "The New Economic Geography of Automobile Production: Japanese Transplants in North America," Economic Geography, 64, no. 4 (October), 352-373.

Massenot, Baptiste and Yuri Pettinicchi, 2018. "Can firms see into the future? Survey evidence from Germany," Journal of Economic Behavior \& Organization, 145, 66-79.

Mattioli, Dana and Konrad Putzier, 2020. "When It's Time to Go Back to the Office, Will It Still Be There?" Wall Street Journal, 16 May.

McCartney, Scott, 2020. "How Strict Are Airlines about Face Masks in Fight?" Wall Street Journal, 18 June 2020.

Mims, Christopher, 2020. "Not Even a Pandemic Can Slow Down the Biggest Tech Giants," Wall Street Journal, 23 May 2020.

Mitchell, Matthew D., 2020. "First, Do No Harm: Three Ways that Policymakers Can Make It Easier for Healthcare," Mercatus Special Edition Policy Brief, 24 March.

Mitchell, Matthew D., Alise Amez-Droz, and Anna K. Parsons, 2020. "Phasing Out Certificateof-Need Laws: A Menu of Options,” Mercatus Center Policy Brief, 7 February.

Mitchell, Matthew D. and Christopher Koopman, 2016. "40 Years of Certificate-of-Need Laws Across America," Mercatus Center, 27 September.

Morath, Eric, 2020. “The Job Market’s Long Road Back,” Wall Street Journal, 23 May 2020.

Omeokwe, Amara, 2020. "Lawmakers in Congress Press for Changes in Small-Business Aid Program," Wall Street Journal, updated 3 May.

Pagano, Marco, Christian Wagner and Joseph Zechner, 2020. "Disaster Resilience and Asset Prices," COVID Economics: Vetted and Real-Time Papers, Issue 21, 22 May.

Papanikolaou, Dimitris and Lawrence D.W. Schmidt, 2020. "Working Remotely and the SupplySide Impact of COVID-19," NBER Working Paper No. 27330. 
Prang, Allison, 2020. "Small Businesses Need Money - But First They Need the U.S. to Reopen," Wall Street Journal, 17 April.

Ramelli, Stefano and Alexander F. Wagner, 2020. "Feverish Stock Price Reactions to COVID19," Swiss Finance Institute Research Paper No. 20-12, 21 April.

Shiller, Robert J., 1981. "Do Stock Prices Move Too Much to Be Justified by Subsequent Changes in Dividends?" American Economic Review, 71, 421-436.

Shiva, Mehdi, 2020. "We Need a Better Head Start for the Next Pandemic," VOX CEPR Policy Portal, 26 April 2020.

Sider, Alison, 2020a. "Airlines Have the Cash. Now They Need the Passengers," Wall Street Journal, 15 April.

Sider, Alison, 2020b. "U.S. Airlines Brace for Slow Recovery as Coronavirus Losses Mount," Wall Street Journal, 2 May.

Sider, Alison, 2020c. "American Airlines to Cut $30 \%$ of Management and Administrative Staff," Wall Street Journal, 27 May 2020.

Stafford, Phillip, Tim Bradshaw, Kana Inagaki, Tabby Kinder and Silvia Sciorilli Borrelli, 2020. "Six Business Finding an Upside in the Coronavirus Pandemic," Financial Times, 1 June.

Tanaka, Mari, Nicholas Bloom, Joel M. David and Maiko Koga, 2019. "Firm Performance and Macro Forecast Accuracy," Journal of Monetary Economics, forthcoming.

Taylor, Kate, 2020. “3 Million out of Work, \$25 Billion Lost, 8 Figures Reveal How the Coronavirus Pandemic Is Devastating Restaurants across America," Business Insider, 31 March 2020.

The Editorial Board, "Doctors Without State Borders: Governors Are Easing Rules on Caregivers, and It's Long Overdue," Wall Street Journal, 12 April.

Thierer, Adam and Trace Mitchell, 2020. "Occupational Licensing Reform and the Right to Earn a Living: A Blueprint for Action," Policy Brief, Mercatus Center, April.

Thomas, Patrick and Chip Cutter, 2020. "Companies Cite New Government Benefit in Cutting Workers," Wall Street Journal, 7 April.

Tyko, Kelly, 2020. “Lowe’s Hiring for 30,000 New Positions, Giving Employees \$80 Million in Bonuses Because of Coronavirus," USA Today, 25 March.

Weber, Lauren, 2020. “50,000 Jobs, 900,000 Resumes: Coronavirus Is Redeploying Workers at Record Pace," Wall Street Journal, 15 April.

Upwork, 2020. 2020 Future Workforce Report.

U.S. Department of the Treasury Office of Economic Policy, 2015. “Occupational Licensing: A Framework for Policy Makers.” Report prepared by Council of Economic Advisers, Department of the Treasury, and the Department of Labor.

Weidinger, Matt, 2020. "Extended: A Review of the Current and Proposed Duration of 'Pandemic' Unemployment Benefits," American Enterprise Institute, June.

Williams, Noah, 2020. "Unemployment Benefits Under the Federal COVID-19 Relief Package," Center for Research on the Wisconsin Economy, 27 March 2020. 
Table 1: Average Values of Expected Growth Rates and Expected Excess Reallocation Rates from September 2016 to January 2020

\begin{tabular}{|c|c|c|c|}
\hline \multicolumn{2}{|c|}{ Expected Growth Rates } & \multicolumn{2}{c|}{ Expected Excess Reallocation Rates } \\
\hline Sales & Jobs & Sales & Jobs \\
\hline 4.36 & 1.59 & 0.97 & 2.23 \\
\hline
\end{tabular}

Notes: Authors' calculations using data from the Survey of Business Uncertainty. We compute the indicated activity-weighted statistic for each month from September 2016 to January 2020, and we then average over months to obtain the entries reported in the table.

Table 2: Anticipated Coronavirus Impact on 2020 Sales Revenue, Percentage Amounts

Survey Question: What's your best guess for the impact of coronavirus developments on your firm's sales revenues in 2020? (Response options are a respondent-supplied percentage amount, up or down, and no effect.)

Survey Response Period: April 13-24, 2020

\begin{tabular}{|c|c|c|}
\hline $\begin{array}{c}\text { (1) Activity-Weighted Mean } \\
\text { (Standard Error) }\end{array}$ & $\begin{array}{c}\text { (2) Reweighted to Match the } \\
\text { U.S. Industry Distribution }\end{array}$ & $\begin{array}{c}\text { (3) Number of } \\
\text { Survey Respondents }\end{array}$ \\
\hline$-17.6(0.9)$ & $-18.9(0.9)$ & 394 \\
\hline
\end{tabular}

Notes: Authors' calculations using data from the April Survey of Business Uncertainty. Column (1) reports activity-weighted means in the April sample. Column 2 reports means after further weighting the sample observations to match the one-digit industry distribution of private sector gross output. According to the BEA, gross output is, "principally, a measure of an industry's sales or receipts ... [and capture] an industry's sales to consumers and other final users (found in GDP), as well as sales to other industries (intermediate inputs not counted in GDP). They reflect the full value of the supply chain by including the business-to-business spending necessary to produce goods and services and deliver them to final consumers." See Altig, Barrero et al. (2020a) for additional information. 
Table 3: Gross Staffing Changes in Reaction to the COVID-19 Pandemic

Survey Questions: We would also like to ask how developments related to the coronavirus are affecting staffing levels at your firm

- Since March 1, we made the following staffing changes in response to developments related to the coronavirus. (Response options as indicated below.)

- Over the next four weeks, we expect to make the following staffing changes in response to developments related to the coronavirus. (Response options as indicated below.)

Survey Response Period: April 13-24, 2020

\begin{tabular}{|l|l|l|l|}
\hline $\begin{array}{l}\text { Entries are activity-weighted means, expressed } \\
\text { as a percent of employment on March 1 }\end{array}$ & $\begin{array}{l}\text { From March 1 } \\
\text { to Mid-April }\end{array}$ & $\begin{array}{l}\text { Over Next } \\
\text { Four Weeks }\end{array}$ & Cumulative \\
\hline Net staffing change, Exclusive of Quits & $-10.0(1.18)$ & $-0.9(2.02)$ & $-10.8(2.62)$ \\
\hline Net staffing change, with Imputed Quits & -12.2 & -1.7 & -13.7 \\
\hline Gross staffing reductions, Exclusive of Quits & $10.9(1.16)$ & $4.0(0.69)$ & $14.9(1.62)$ \\
\hline Gross staffing reductions, with Imputed Quits & 13.1 & 4.8 & 17.8 \\
\hline Permanent layoffs & $0.9(0.18)$ & $0.7(0.23)$ & $1.5(0.34)$ \\
\hline Temporary layoffs and furloughs & $8.5(0.95)$ & $2.9(0.49)$ & $11.4(1.28)$ \\
\hline Cuts in contractors and leased workers & $1.6(0.63)$ & $0.5(0.36)$ & $2.0(0.85)$ \\
\hline Imputed Quits & 2.2 & 0.8 & 2.9 \\
\hline Gross staffing increases & $0.9(0.16)$ & $3.1(1.88)$ & $4.1(2.05)$ \\
\hline Hires of new employees & $0.8(0.16)$ & $3.0(1.88)$ & $3.9(2.04)$ \\
\hline Additions to contractors and leased workers & $0.1(0.03)$ & $0.1(0.05)$ & $0.2(0.06)$ \\
\hline Number of survey responses & 368 & 341 & 335 \\
\hline
\end{tabular}

Notes: Authors' calculations using data from the April 2020 Survey of Business Uncertainty. Standard errors in parentheses. According to data from the Job Opening and Labor Turnover Survey, there were 0.2314 quits per layoff in March 2020 and 0.2191 in April. We multiply these fractions by the SBU layoff rates in the table to obtain imputed quits. 
Table 4: Working from Home before and after the COVID-19 Pandemic

Survey of Business Uncertainty Questions:

- What percentage of your full-time employees worked from home in 2019?

- What percentage of your full-time employees will work from home after the coronavirus pandemic?

Survey Response Period: May 11-22, 2020

\begin{tabular}{|c|c|c|c|c|c|}
\hline \multirow[b]{2}{*}{$\begin{array}{l}\text { Survey of Business Uncertainty } \\
\text { (May 2020) }\end{array}$} & \multicolumn{5}{|c|}{$\begin{array}{c}\text { (Employment-weighted mean) share of employees } \\
\text { who... }\end{array}$} \\
\hline & $\begin{array}{l}\text { Rarely } \\
\text { or never }\end{array}$ & $\begin{array}{c}1 \text { full } \\
\text { day per } \\
\text { week }\end{array}$ & $\begin{array}{c}2 \text { to } 4 \\
\text { full days } \\
\text { per week }\end{array}$ & $\begin{array}{c}5 \text { full } \\
\text { days per } \\
\text { week }\end{array}$ & $\begin{array}{l}\text { Paid working } \\
\text { days at home } \\
\text { as a percent of } \\
\text { all working } \\
\text { days }\end{array}$ \\
\hline ... worked from home in $2019 ?$ & $\begin{array}{l}90.3 \% \\
(1.11)\end{array}$ & $\begin{array}{l}3.4 \% \\
(0.52)\end{array}$ & $\begin{array}{l}2.9 \% \\
(0.41)\end{array}$ & $\begin{array}{l}3.4 \% \\
(0.56)\end{array}$ & $\begin{array}{c}5.5 \% \\
(0.70)\end{array}$ \\
\hline $\begin{array}{l}\text {... will work from home after } \\
\text { the coronavirus pandemic? }\end{array}$ & $\begin{array}{l}73.0 \% \\
(1.97)\end{array}$ & $\begin{array}{l}6.9 \% \\
(0.64)\end{array}$ & $\begin{array}{l}9.9 \% \\
(0.94)\end{array}$ & $\begin{array}{l}10.3 \% \\
(1.23)\end{array}$ & $\begin{array}{l}16.6 \% \\
(1.41)\end{array}$ \\
\hline $\begin{array}{l}\text { American Time Use Survey } \\
(2017-2018)\end{array}$ & $\begin{array}{l}\text { Rarely } \\
\text { or never }\end{array}$ & $\begin{array}{c}1 \text { full } \\
\text { day per } \\
\text { week }\end{array}$ & $\begin{array}{c}2 \text { to } 4 \\
\text { full days } \\
\text { per week }\end{array}$ & $\begin{array}{c}5 \text { full } \\
\text { days per } \\
\text { week }\end{array}$ & $\begin{array}{l}\text { Paid working } \\
\text { days at home } \\
\text { as a percent of } \\
\text { all working } \\
\text { days }\end{array}$ \\
\hline $\begin{array}{l}\text {... work from home in } \\
\text { 2017/2018? }\end{array}$ & $89.8 \%$ & $3.8 \%$ & $3.8 \%$ & $2.6 \%$ & $5.2 \%$ \\
\hline
\end{tabular}

Notes: In computing the SBU statistics, we weight each firm by its employment and further weight industries to match the one-digit distribution of payroll employment in the US economy. We drop firms with responses that don't sum to approximately 100 percent across the response options for a given question. We also drop firms that clearly misinterpreted the pre-COVID question as asking about the situation during the pandemic. The resulting sample has 279 observations for the 2019 question and 280 for the post-pandemic question. ATUS data cover full-time workers. We compute the number of paid working days at home as a percent of all working days by converting the number of days at home to a fraction of the workweek ( 0.2 for 1 day, 0.5 for $2-4$ days, and 1 for 5 days) and multiplying by the respective share in each category.

Sources: Bureau of Labor Statistics (BLS) ATUS (www.bls.gov/news_release/flex2.t03.htm); Survey of Business Uncertainty conducted by the Federal Reserve Bank of Atlanta, Stanford University, and the University of Chicago Booth School of Business; authors' calculations. 
Table 5: Working from Home before and after the COVID-19 Pandemic by Major Industry Sector

Survey Questions:

- What percentage of your full-time employees worked from home in 2019?

- What percentage of your full-time employees will work from home after the coronavirus pandemic?

Survey Response Period: May 11-22, 2020

\begin{tabular}{|l|c|c|}
\hline & \multicolumn{2}{|c|}{$\begin{array}{c}\text { Full working days at home as a } \\
\text { percent of all paid working days }\end{array}$} \\
\hline & 2019 & $\begin{array}{c}\text { After the coronavirus } \\
\text { pandemic }\end{array}$ \\
\hline Overall & $5.5 \%(0.70)$ & $16.6 \%(1.41)$ \\
\hline $\begin{array}{l}\text { Finance, Insurance, Professional } \\
\text { Services and Business Services }\end{array}$ & $10.7 \%(1.88)$ & $29.2 \%(2.96)$ \\
\hline $\begin{array}{l}\text { Education, Health and Other } \\
\text { Services Except Government }\end{array}$ & $4.6 \%(1.62)$ & $14.1 \%(3.69)$ \\
\hline Manufacturing & $6.8 \%(1.50)$ & $11.5 \%(1.91)$ \\
\hline Retail and Wholesale Trade & $2.6 \%(1.00)$ & $7.4 \%(2.27)$ \\
\hline $\begin{array}{l}\text { Construction, Real Estate, } \\
\text { Mining, and Utilities }\end{array}$ & $1.4 \%(0.44)$ & $22.4 \%(4.97)$ \\
\hline
\end{tabular}

Notes: See notes to Table 4.

Source: Survey of Business Uncertainty conducted by the Federal Reserve Bank of Atlanta, Stanford University, and the University of Chicago Booth School of Business; authors' calculations. 
Figure 1: Expected Rates of Employment Growth and Excess Job Reallocation at Twelve-Month Forecast Horizons, September 2016 to June 2020

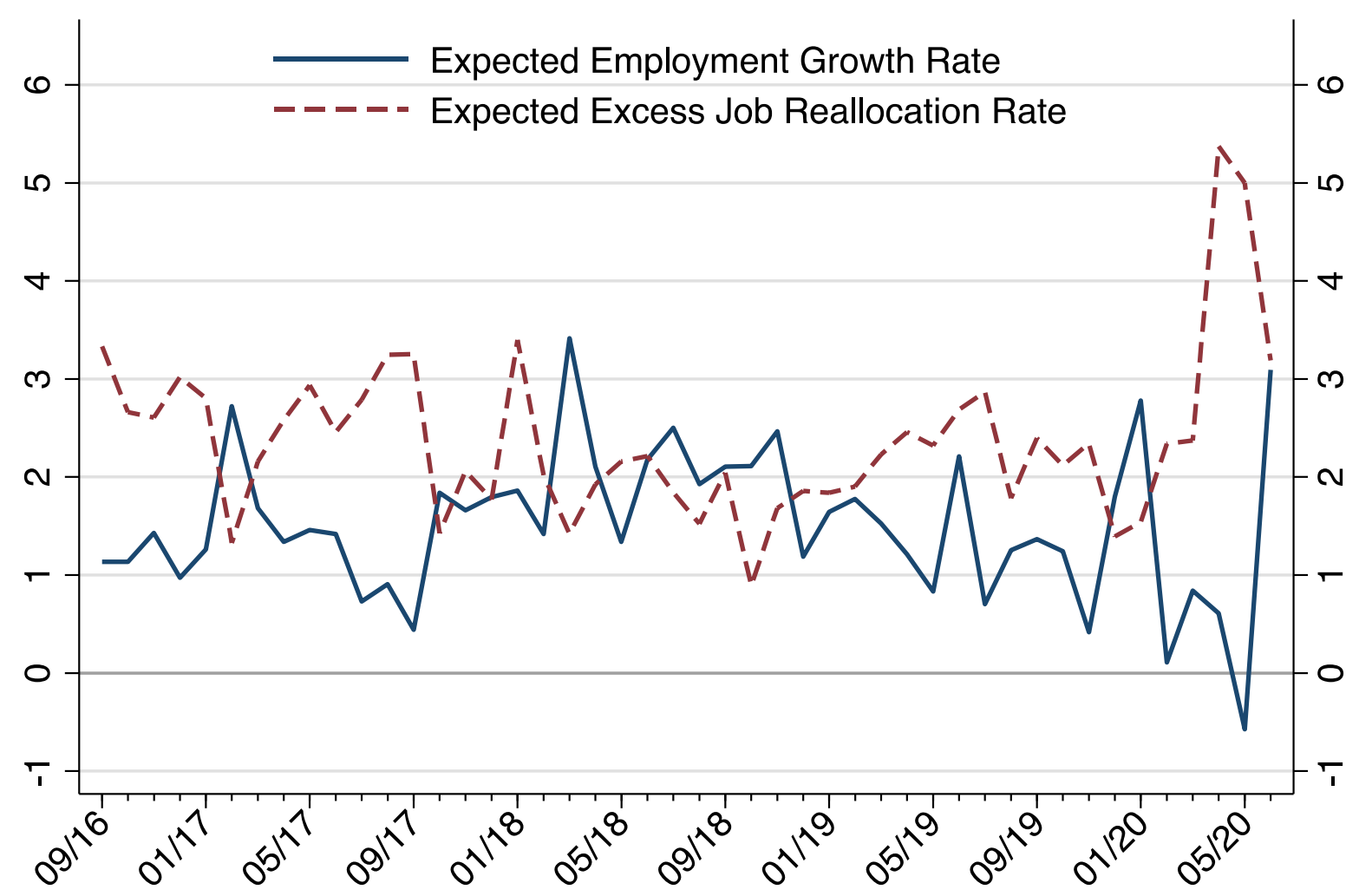

Source: Authors' calculations using data from the Survey of Business Uncertainty. 
Figure 2: Expected Rates of Sales Growth and Excess Sales Reallocation at Four-Quarter Forecast Horizons, September 2016 to June 2020

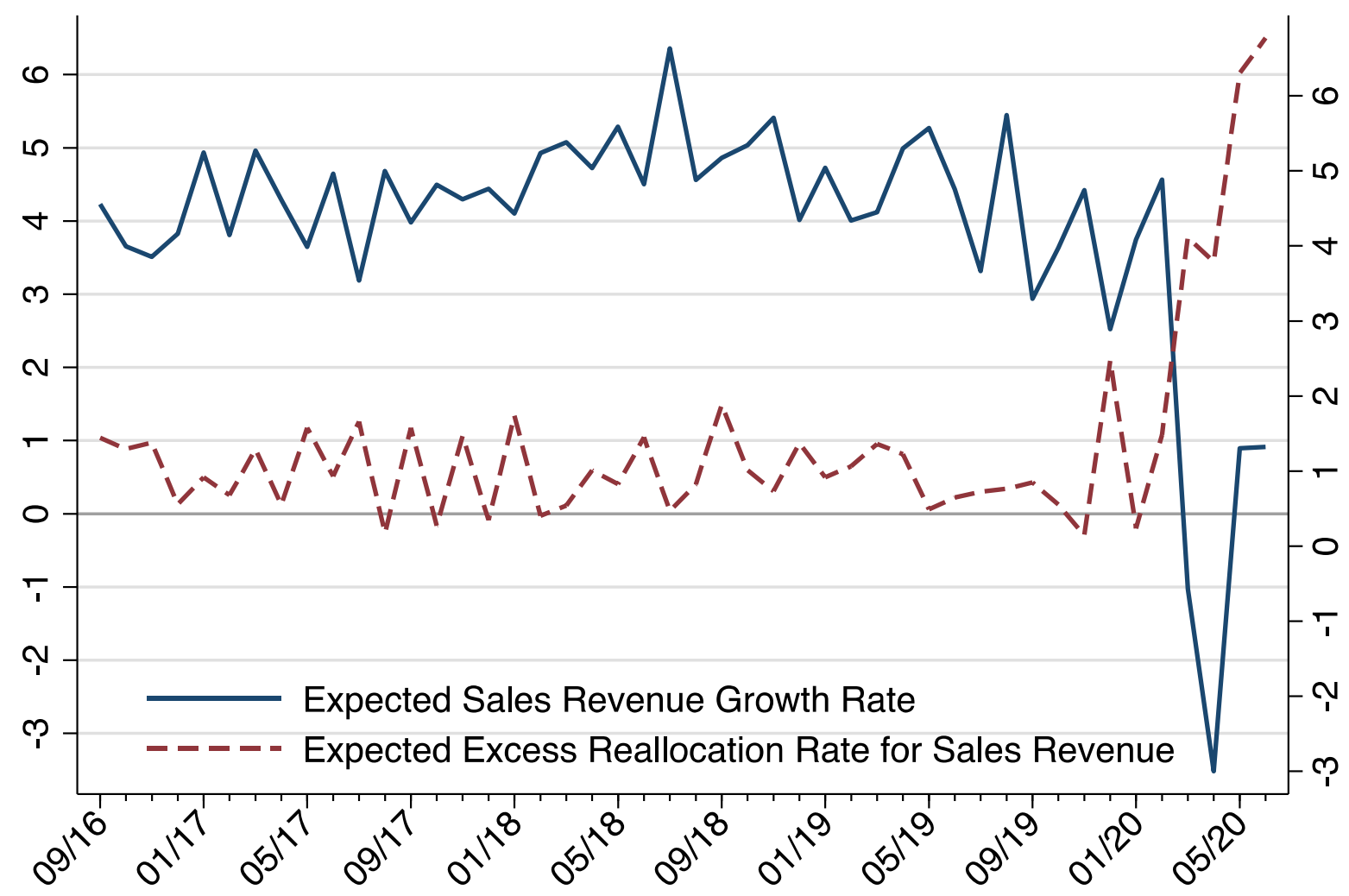

Source: Authors' calculations using data from the Survey of Business Uncertainty. 
Figure 3: Weekly Count of High-Propensity Business Applications in 2020 and Percent Change Relative to the Same Week in 2019

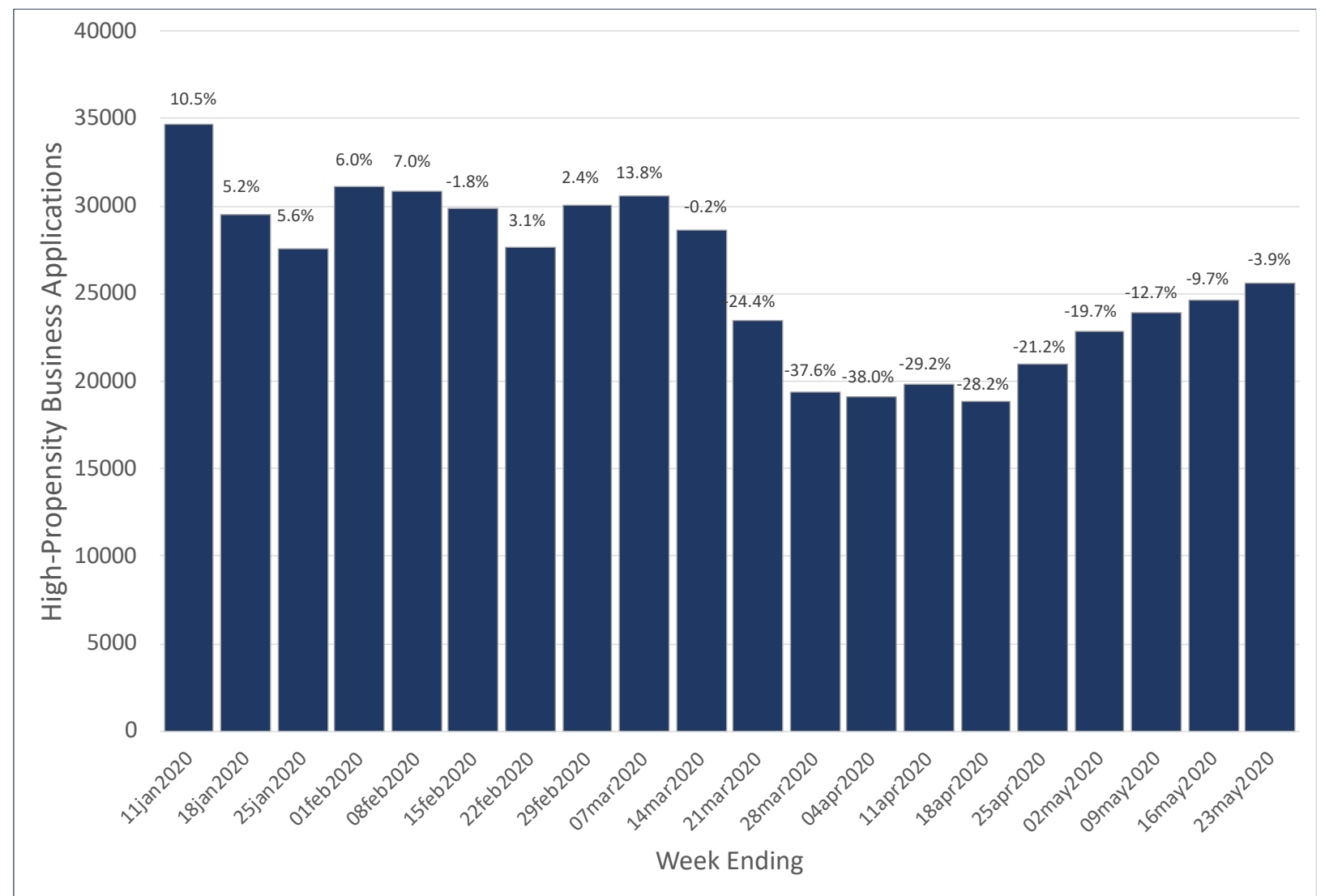

Source: Weekly Business Formation Statistics, U.S. Census Bureau

Notes: Bar heights report the count of "High-Propensity Business Applications" in the week ending on the indicated date. These statistics derive from administrative data on applications for a new Employer Identification Number (EIN) on IRS Form SS-4. "High-propensity" applications are those with a high propensity to hire paid employees based on certain characteristics, including (a) they are from a corporate entity; (b) they indicate they are hiring employees, purchasing a business or changing organizational type; (c) they provide a first wages-paid date (planned wages); or (d) they have a NAICS industry code in manufacturing (31-33), retail stores (44), health care (62), or restaurants/food service (72). The values atop each bar are year-on-year percent changes in the number of high-propensity business applications relative to the same week in 2019. 
Figure 4: Working from Home Accounts for More Than 60 Percent of U.S. Labor Services Supplied in May 2020

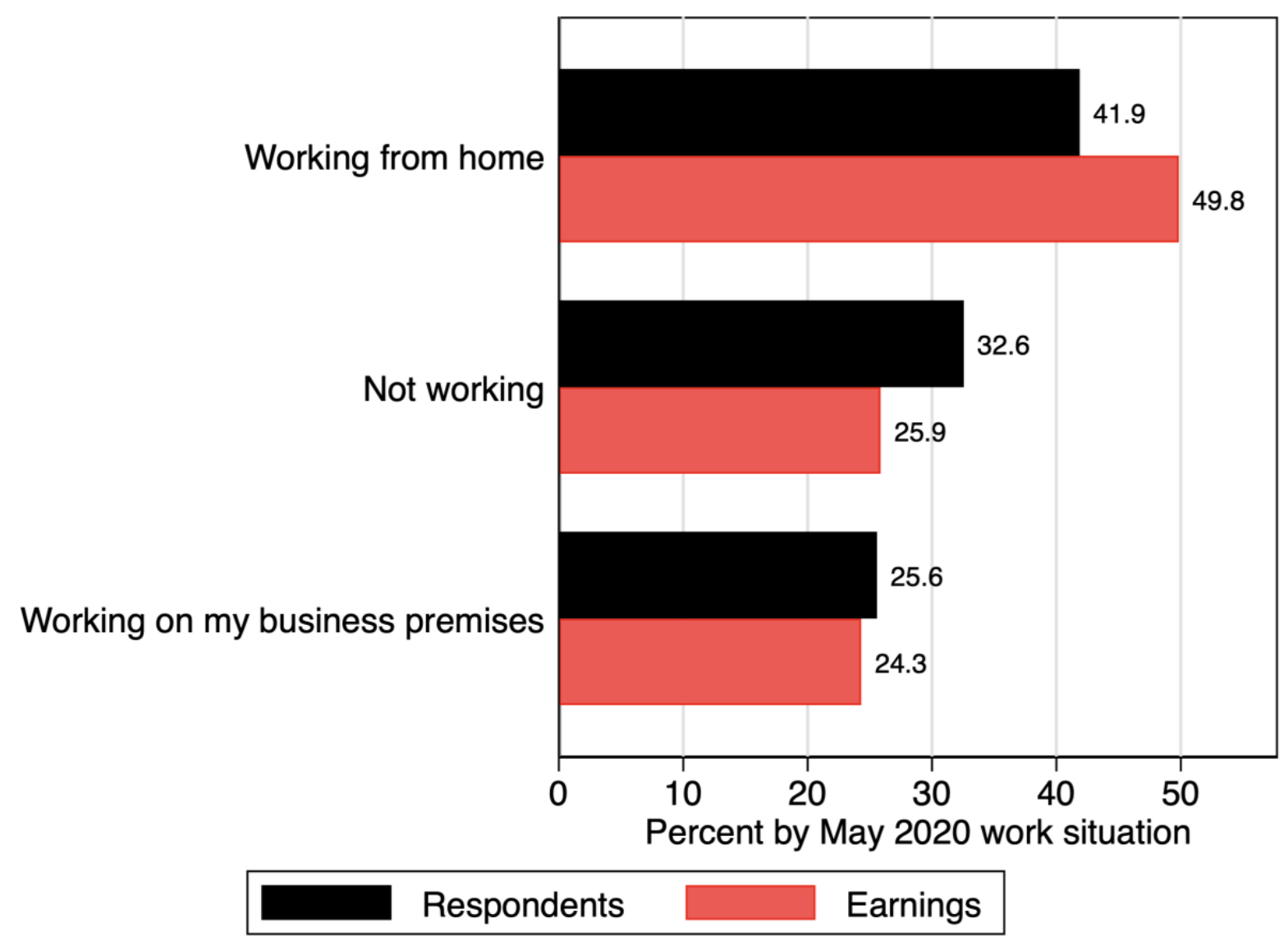

Notes: This chart summarizes responses to the following question: "Currently (this week) what is your work status?" Response options are "Working on my business premises," "Working from home," "Still employed and paid, but not working," "Unemployed, but expect to be recalled to my previous job," "Unemployed, and do not expect to be recalled to my previous job," and "Not working, and not looking for work." The data are from a survey of 2,500 U.S. residents aged 20 to 64, earning more than $\$ 20,000$ per year in 2019 fielded from 21-29 May by QuestionPro on behalf of Stanford University. We re-weight the sample to match the share of individuals at the level of cells defined by cross product of earnings interval, state and industry (using the current or most recent job) in CPS data from 2010 to 2019. Adjusting for those not working, the results displayed in the bar chart say that $(41.9 /(100-32.6)=62$ percent of labor services were supplied from home as of late May (67 percent on an earnings-weighted basis). 
Figure 5: The Dispersion of Firm-Level Stock Returns, January 1984 to May 2020

\section{A. Interquartile Range of the Value-Weighted Equity Return Distribution}

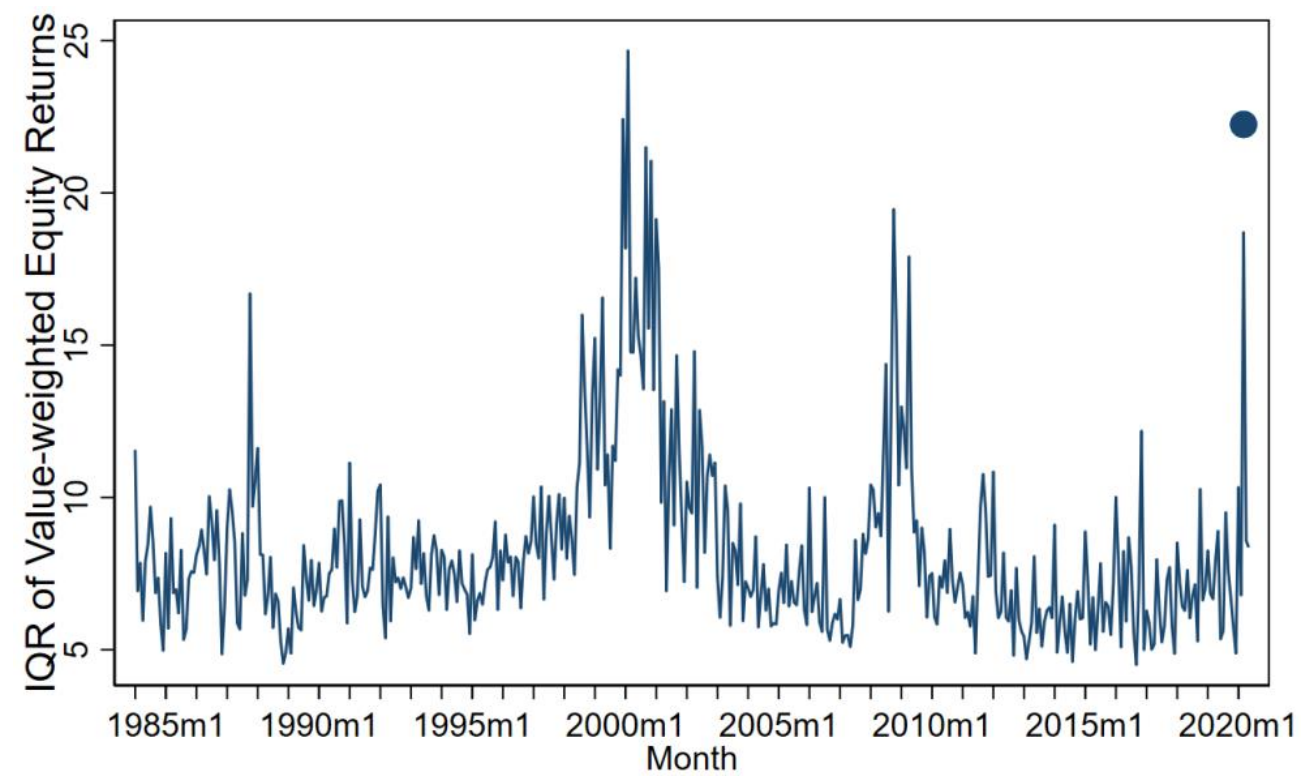

\section{B. Standard Deviation of the Value-Weighted Equity Return Distribution}

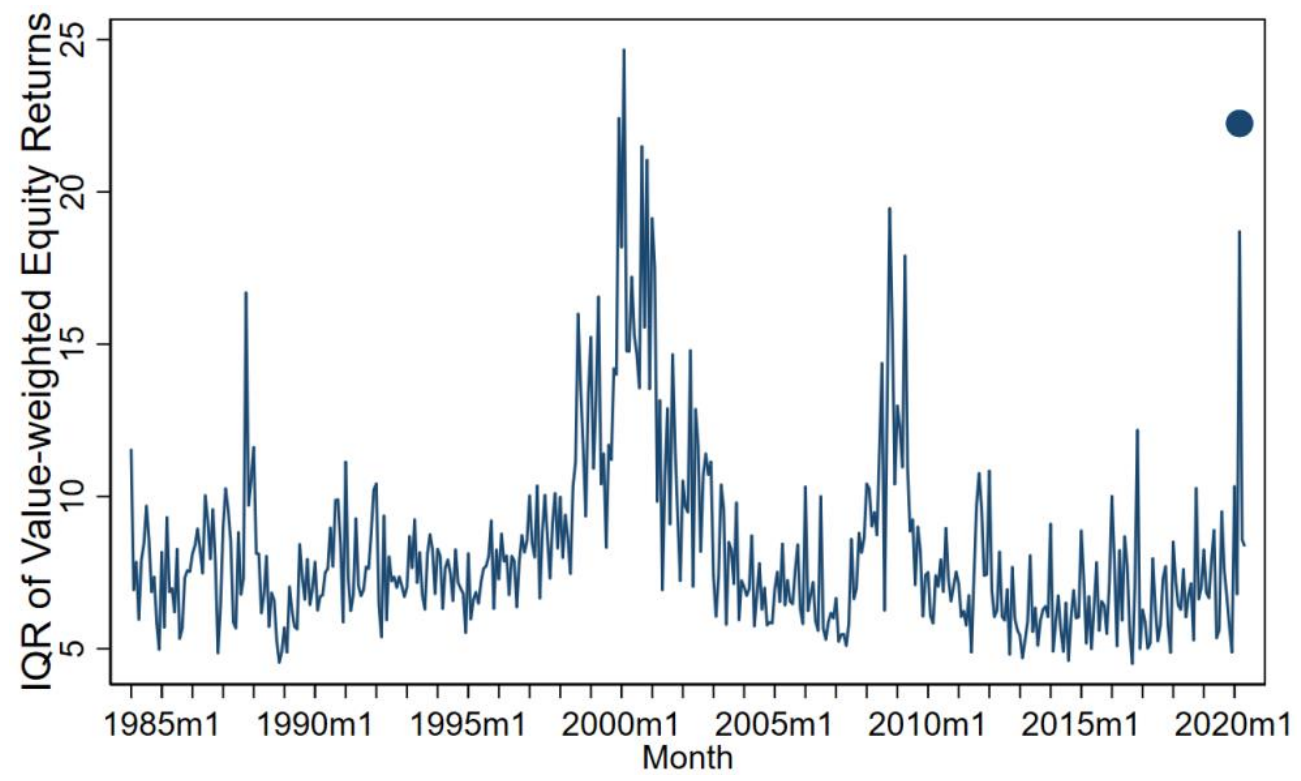

Notes: We consider common equity securities traded on the NYSE, AMEX and NASDAQ with share prices quoted in U.S. Dollars. Data are from Compustat - Capital IQ Daily Security Files and from CRSP, both via the Wharton Research Data Services. We compute returns for month $t$ as 100 times the log change of closing prices on the last trading days in months $t-1$ and $t$ with adjustments for dividends, share repurchases, stock splits and reverse splits. The large dots reflect log changes from 24 February to 21 March 2020. 


\section{Appendix A: Inferring the Permanent-Layoff Share of Job Losses from CPS Statistics}

The monthly BLS Employment Situation Summary (ESS) reports statistics on unemployment by reason based on data from the Current Population Survey of households. Table A-11 in the April 2020 ESS, issued on 8 May, reports 2.56 million permanent job losers (including persons who completed temporary jobs) among the 23.08 million persons classified as unemployed.44 That is, the CPS data say that 11 percent of unemployed persons in April had permanently lost their jobs. However, this 11 percent figure is not the share of layoffs that are permanent, nor is it the share perceived as permanent at the time of job loss.

Estimating the Permanent-Layoff Share of Job Losses between the March and April Surveys To obtain a rough CPS-based estimate for the April 2020 share of recent job losses that are perceived as permanent at the time of job loss, we proceed as follows. First, 14.28 million persons became newly unemployed within the previous 5 weeks, according to the April CPS. We treat all of these persons as recent job losers. Second, CPS statistics for the number of persons unemployed 5-14 weeks rose by 5.21 million from March to April, which is too large to be consistent with the February CPS figure of 1.80 million persons who then reported an ongoing unemployment spell of less than five weeks duration. It is well known that survey data on the duration of ongoing unemployment spells are subject to recall bias and reporting errors. Accordingly, we treat the gap, $(5.21-1.80)=3.41$ million, as persons who actually lost jobs between the March and April surveys. Summing yields $14.28+3.41=17.69$ million persons who lost jobs between the March and April surveys. Third, recall that a worker who experiences a permanent job loss and does not search is classified as out of the labor force, not unemployed. We need an estimate for these persons as well to obtain a CPS-based estimate for total number of job losers between the March and April surveys.

Given the very rough labor market conditions that prevailed in April 2020 (and the second half of March), fears about contracting the virus on the job, and new-found needs to care for school-age children at home, many persons who experienced a permanent job loss between the March and April surveys likely chose not to search for a new job and, hence, did not show up

${ }_{44}$ We use seasonally adjusted CPS statistics unless noted otherwise. 
in the April unemployment statistics. (Job losers on temporary layoff are counted as unemployed, whether they search or not.) Indeed, according to CPS data, the labor force fell by 6.4 million persons from the March survey to the April survey. We treat this (historically large) fall as a response to the COVID-19 pandemic.

The March-April fall in the labor force includes (a) persons who lost jobs between the March and April surveys and left the labor force, (b) a fall in "Reentrants" and "New Entrants" to the unemployment pool from March to April, and (c) persons unemployed as of the March survey who left the labor force by the April survey. We seek an estimate for item (a). Published CPS statistics imply that item (b) equals 421,000. The number of people unemployed for 15 weeks or more fell by 200 thousand from March to April. We treat all of these persons as having left the labor force. Thus, we estimate that $6.43-0.42-0.20=5.81$ million persons experienced a job loss between the March and April surveys and left the labor force.45 Adding this figure to the 17.69 million figure above, we obtain our CPS-based estimate for the number of persons who lost jobs between the March and April surveys: $5.81+17.69=23.5$ million.

How many of those new job losses were perceived to be permanent as of the April survey date? 5.81 million plus the fraction of the 17.69 million that met the CPS criteria for unemployment and permanent job loss. To our knowledge, the published CPS statistics don't include a two-way breakdown of unemployment by reason and duration. So, we use the overall fraction of unemployed job losers who are permanently laid off, according to the April CPS. That fraction is $(2,563 / 20,626)=12.4 \%$. Multiplying this figure by 17.69 million yields 2.19 million. Adding this figure to our previous estimate for the number of new job losers who left the labor force yields a total of $5.81+2.19=8.0$ million permanent layoffs between the March and April surveys. Finally, computing the ratio of permanent layoffs to all job losses, we estimate that $8.0 / 23.5=34$ percent of new job losses in April were perceived as permanent at the time.

45 Three other assumptions are implicit in our calculation. First, we effectively grouped persons who quit jobs to leave the labor force with persons who lost jobs and left the labor force. Second, we ignored persons who transitioned directly from out of the labor force to employment. Including these latter transitions would increase the implied number of gross exits from the labor force and raise our estimate for the number of persons who lost jobs and left the labor force. Third, we ignored persons who lost jobs in a permanent layoff and found another job between surveys. Including an estimate for these transitions would also raise our estimate for the number of permanent layoffs. 


\section{Concerns Related to the CPS-Based Estimate of the Permanent-Layoff Share}

Undoubtedly, one could obtain a better estimate for the fraction of new job losses perceived as permanent as of mid-April 2020 by working with the CPS micro data. However, we see no reason to think that using micro data will alter our conclusion that permanent layoffs account for a large share of recent job losses.

There are, however, several other matters that warrant attention. First, as discussed in the main text, a sizable share of layoffs perceived as temporary when they happen turn out to be permanent ex post. We think the same will be true of recent job losses reflected in the CPS. In fact, the gap between initial perceptions and eventual realizations may prove considerably larger in the wake of the COVID-19 pandemic than in the past.

Second, there was a major change to CPS interview guidance in March and April that inflates the CPS temporary layoff numbers. Basically, if a respondent mentioned the coronavirus as the reason for job loss and expressed uncertainty about whether he/she would be recalled to his/her lost job within 6 months or did not know how to answer the question, the interviewer was instructed to code the response as on "temporary layoff" rather than "don't know."

The interview guidance is described at www.bls.gov/cps/employment-situation-covid19faq-april-2020.pdf, and the relevant passage reads as follows:

8. Household survey: Were interviewers provided with any special guidance?

Due to the unusual circumstances related to the pandemic, additional guidance was provided to Census Bureau interviewers prior to collecting data in April. This was similar to the guidance that had been provided in March. In both months, guidance was provided only for the three items discussed below. Information was not provided for other survey questions.... For those who did not work at all during the survey reference week of April 12-18, if a person indicated they were under quarantine or self-isolating due to health concerns, the interviewer should select "own illness, injury, or medical problem." For people who were not ill or quarantined but said that they did not work last week "because of the coronavirus," the interviewer should select "on layoff (temporary or indefinite)." This scenario would include people who reported "I work at a sports arena and everything is postponed" or "the restaurant closed for now because of the coronavirus." To be classified as unemployed on temporary layoff, a person has either been given a date to return to work by their employer or expects to be recalled to their job within 6 months. Additional guidance was also provided to household survey interviewers regarding the question "Have 
you been given any indication that you will be recalled to work within the next 6 months?" If, because of the coronavirus, a person was uncertain of when they would be able to return to work and thus was unsure of how to answer the question, the interviewer was instructed to enter a response of "yes," rather than "don't know." This would allow the individual to be included among the unemployed on temporary layoff. In light of the uncertainty of circumstances related to the pandemic, this unusual step was taken as part of an attempt to classify people who were effectively laid off due to pandemic-related closures among the unemployed on temporary layoff.

In short, the guidance instructs interviewers to classify pandemic-related layoffs as temporary, unless the respondent confidently states otherwise. It's hard to know how much this interview guidance inflates the temporary-layoff share of recent job losses, but it likely leads to a material upward bias. As we report in Appendix B, 12.9 percent of new claimants for unemployment benefits in California during the period from March to May 2020 said their layoff status (temporary or permanent) was unknown as of their claim filing date.

A third matter cuts in the other direction. The BLS notes that the April 2020 CPS data include an extraordinarily high number of persons classified as "employed with a job but not at work" for "other reasons." There were 7.53 million more such persons in April 2020 than in April 2019.46 The BLS also notes that its "analysis of the underlying data suggests that this group included workers affected by the pandemic response who should have been classified as unemployed on temporary layoff." If we treat the entire 7.53 million increase in April 2020 (relative to April 2019) as unemployed on temporary layoff, our estimate for the share of recent job losses that are permanent becomes $8.0 /(23.5+7.5)=26$ percent.

Finally, it's worth noting that the CPS household response rate in April 2020 is 70 percent, 13 percentage points lower than both April 2019 and the twelve months ending in February 2020.

46 See the FAQs at www.bls.gov/cps/employment-situation-covid19-faq-april-2020.pdf. The 7.53 million figure is from Table $\mathrm{C}$ and is not seasonally adjusted. 


\section{Appendix B: Projections for the Permanent-Layoff Share of COVID-Induced Job Losses}

Table B.1 reports 12 projections for the percentage of COVID-induced layoffs that will turn out to be permanent in the sense that the job-losing worker does not return to his previous employer. These projections rely on six alternative estimates for the fraction of layoffs perceived as permanent at the time of job loss. For each such estimate, we draw on two studies that provide information about the realized recall rate for "temporary" and "permanent" layoffs in previous historical episodes. Thus, we obtain 6 times $2=12$ projections.

Table B.2 Projections of the Permanent-Layoff Share of Pandemic Job Losses

\begin{tabular}{|l|l|c|c|c|}
\hline & $\begin{array}{l}\text { Respondents and } \\
\text { Sample Period }\end{array}$ & $\begin{array}{l}\text { (A) Layoff Share } \\
\text { Perceived as } \\
\text { Permanent at the } \\
\text { Time of Job Loss }\end{array}$ & $\begin{array}{l}\text { Projected Permanent-Layoff Share, } \\
\text { Using Realized Recall Rates in: }\end{array}$ \\
\cline { 5 - 6 } & $\begin{array}{l}\text { (B) Katz and } \\
\text { Meyer (1990) }\end{array}$ & $\begin{array}{l}\text { (C) Fujita and } \\
\text { Moscarini (2017) }\end{array}$ \\
\hline $\begin{array}{l}\text { (1) Survey of } \\
\text { Business } \\
\text { Uncertainty }\end{array}$ & $\begin{array}{l}\text { Senior Business } \\
\text { Executives, 13-24 } \\
\text { April 2020 }\end{array}$ & $23.5 \%$ & $41.9 \%$ & $31.5 \%$ \\
\hline $\begin{array}{l}\text { (2) Washington } \\
\text { Post/IPSOS Poll } \\
\text { (2020) }\end{array}$ & $\begin{array}{l}\text { Households, 27 } \\
\text { April to 4 May } \\
\text { 2020 }\end{array}$ & $23 \%$ & $41.6 \%$ & $31.1 \%$ \\
\hline $\begin{array}{l}\text { (3) CPS, Low } \\
\text { Estimate }\end{array}$ & $\begin{array}{l}\text { March and April } \\
\text { Household } \\
\text { Surveys }\end{array}$ & $26 \%$ & $36.4 \%$ & $30.4 \%$ \\
\hline $\begin{array}{l}\text { (4) CPS, High } \\
\text { Estimate }\end{array}$ & $\begin{array}{l}\text { March and April } \\
\text { Household } \\
\text { Surveys }\end{array}$ & $34 \%$ & $48.1 \%$ & $40.0 \%$ \\
\hline $\begin{array}{l}\text { (5) Upwork } \\
\text { (2020) }\end{array}$ & $\begin{array}{l}\text { Hiring Decision } \\
\text { Makers, 22-28 } \\
\text { April 2020 }\end{array}$ & $47 \%$ & $55.7 \%$ & $50.5 \%$ \\
\hline $\begin{array}{l}\text { (6) California } \\
\text { Policy Lab }\end{array}$ & $\begin{array}{l}\text { New UI Claims, in } \\
\text { California, March- } \\
\text { May 2020 }\end{array}$ & $23.2 \%$ & $41.7 \%$ & $31.3 \%$ \\
\hline
\end{tabular}

Notes: The main text develops the entries in Row (1). We obtain the Column (A) entries for Rows (2) and (5) directly from the indicated sources. Appendix A derives the CPS Low and High Estimates in Rows (3) and (4) of Column (A). We calculate the entry in Column (A) of Row (6) using data from the California Policy Labor (CPL) kindly supplied by Muhammad Akhtar and Till von Wachter. The CPL data contain the number of new claimants for unemployment benefits in California who perceive their layoff status to be temporary, permanent, and unknown based on responses to "Do you expect to return to a former employer?" This question is asked at the claimant's initial filing. According to CPL data for for the period 
from March to May in 2020, 16.7 percent of layoffs were perceived as permanent on the filing date, 70.4 percent were perceived as temporary, and 12.9 percent were unknown. Assiging onehalf of the unknown cases to the permanent category yields the 23.2 percent figure reported in the Column (A) of Row (6). The realized recall rates from Katz and Meyer (1990) are 72 percent of "temporary" layoffs and 13 percent of "permanent" layoffs. The realized recall rates supplied by Giuseppe Moscarini (based on Fujita and Moscarini, 2017) are 87.5 percent and 6.6 percent. All values reported in columns (B) and (C) follow the calculations in Section IV.a of the main text, except for the "CPS, Low Estimate" values. In computing these values in Row (3), we assume that 100 percent of the extra 7.53 million persons in April 2020 (relative to April 2019) who were absent from work with pay for "other reasons" will be recalled. 